\title{
80. COMPARISON AND CORRELATION OF PHYSICAL-PROPERTY RESULTS FROM JAPAN SEA BASIN AND RISE SITES, LEGS 127 AND $128^{1}$
}

\author{
D. C. Nobes, ${ }^{2}$ M. G. Langseth, ${ }^{3}$ S. Kuramoto,${ }^{4}$ P. Holler, ${ }^{5}$ and N. Hirata ${ }^{6}$
}

\begin{abstract}
A few characteristics dominate the bulk physical properties of the sedimentary and igneous formations recovered in the Japan Sea on ODP Legs 127 and 128. The sediments above the opal-A/opal-CT boundary have high porosities over a large interval, with associated low wet-bulk densities and acoustic velocities; some of the detailed features in the uppermost sediments appear to correlate from site to site. The high porosities and general degree of underconsolidation are typical of sediments rich in biogenic silica. The diagenetic transformation from opal-A to opal-CT has a considerable effect on the sediment physical properties and serves as a widespread seismic and thermal marker horizon. The physical properties above and below the boundary are distinctly different. Finally, the interbedded igneous and sedimentary units give rise to strongly layered reflective sequences. The igneous units are highly altered, and the degree of alteration, as expressed through the loss on ignition, significantly affects the physical properties; the density and velocity are lower when alteration products such as clay or zeolite are present.
\end{abstract}

\section{INTRODUCTION}

The goals of Ocean Drilling Program (ODP) Legs 127 and 128 were, in part, to determine the nature and age of basement and to examine the paleoceanography of the Japan Sea. The physical properties, in particular, are significantly affected by the processes that govern the nature and rate of sedimentation, sedimentary diagenesis, the accumulation of igneous units, and igneous alteration. A number of individual studies elsewhere in this volume focus on specific topics, and we will refer to many of these detailed papers. It is the purpose of this report to provide, instead, a synthesis and an overview of the physical-property measurements and the subsequent analyses obtained from Legs 127 and 128. We can compare and contrast the properties from a wide geographic range, from basin and rise sites, from sites underlain by continental crust as opposed to oceanic crust, and from sites that appear to be "normal" vs. sites that have been tectonically reactivated. The diagenetic and alteration processes to a great extent dominate the physical-property variations; it is thus perhaps only natural that these effects loom large in our discussions.

Six sites were drilled on Legs 127 and 128 (Fig. 1). Site 794 was drilled on both legs; Sites 795, 796, and 797 were drilled on Leg 127 (Tamaki, Pisciotto, Allan, et al., 1990); and Sites 798 and 799 were drilled on Leg 128 (Ingle, Suyehiro, von Breymann, et al., 1990). Igneous rocks were recovered only at Sites 794, 795, and 797. Sites 796 and 798 are rise sites: Site 796 is on the Okushiri Ridge, which has been uplifted through recent tectonic activity, and Site 798 is on the Oki Ridge. Site 799 is in the Kita-Yamato Trough, between the Kita-Yamato Bank and the Yamato Bank, and may exhibit features that are transitional to the basin sites, 794, 795, and 797. Sites 794 and 797 lie at opposite ends of the Yamato Basin, whereas Site 795 is at the extreme northern end of the Japan Basin. In some sense, then, each site has its own unique characteristics that influence the physical

'Tamaki, K., Suyehiro, K., Allan, J., McWilliams, M., et al., 1992. Proc. ODP, Sci. Results, 127/128, Pt. 2: College Station, TX (Ocean Drilling Program).

${ }^{2}$ Department of Earth Sciences and Department of Physics, University of Waterloo, Waterloo, Ontario N2L 3G1, Canada (Present address: Department of Geology, University of Canterbury, Private Bag 4800, Christchurch, New Zealand).

${ }^{3}$ Lamont-Doherty Geological Observatory, Columbia University, Palisades, NY 10964, U.S.A.

${ }^{4}$ Ocean Research Institute, University of Tokyo, 1-15-1 Minamidai, Nakano-ku, Tokyo 164, Japan.

Geologisch-Paläontologisches Institut der Universität Kiel, Olshausenstrasse 40 2300 Kiel, Federal Republic of Germany.

${ }^{6}$ Department of Earth Sciences, Faculty of Science, Chiba University, 1-33, Yayoicho, Chiba 260, Japan. properties and make general comparison more difficult. Nonetheless, there are some common themes that become apparent as we consider the physical properties, their variations, and their interrelationships.

The physical-property measurement procedures have been outlined in detail elsewhere (e.g., Boyce, 1976; Tamaki, Pisciotto, Allan, et al., 1990; Nobes, Mienert, and Dirksen, 1991) and will not be discussed here. Measurement of the wet volume using the pycnometer can give rise to systematic errors that affect the wet-bulk density, dry-bulk density, and porosity (Nobes et al., chapter 63 , this volume). The physical properties as presented here have been corrected for these errors.

\section{LITHOLOGY}

The lithology of the Japan Sea sites (Fig. 2) is relatively simple (Tamaki, Pisciotto, Allan, et al., 1990; Ingle, Suyehiro, von Breymann, et al., 1990); in general, silty clay overlies diatom ooze and clay, which in turn overlie either diatom claystone or siliceous claystone, depending on the position of the opal-A to opal-CT diagenetic boundary. There are minor differences from site to site. The uppermost sediments at Site 799 , for example, consist of diatom clay, which simply reflects a slightly elevated concentration of what is a minor component at the other sites. The claystone generally contains porcellanite and chert below the opal-A/opal-CT boundary. Basement was recovered at only three sites: 794, 795, and 797. At Sites 794 and 795, a blue tuff is interbedded with the claystone above basement. The nature of the basement rocks varies, and igneous units are interbedded with sedimentary layers.

We note that the Site 796 results are anomalous, as a result of tectonic activity on the Okushiri Ridge (Tamaki, Pisciotto, Allan, et al., 1990), and we will in general restrict our discussions to the other sites. Site 796 has been uplifted and eroded, so that the uppermost sediments are missing. The tectonic activity and the associated high heat flow have altered the physical-property profiles. The remaining sediments are more compacted, and the opal-A to opal-CT transition is less distinct and occurs at shallower depths than at the other sites. In summary, the burial, compaction, high heat flow, uplift, and subsequent erosion at Site 796 have left a sediment section that has lower values of porosity and water content, and consequently has higher wet-bulk densities, acoustic velocities, and thermal conductivities.

\section{POROSITY}

The physical properties of the recovered cores reflect the major influences of high porosity, silica diagenesis (Kuramoto et al., this 


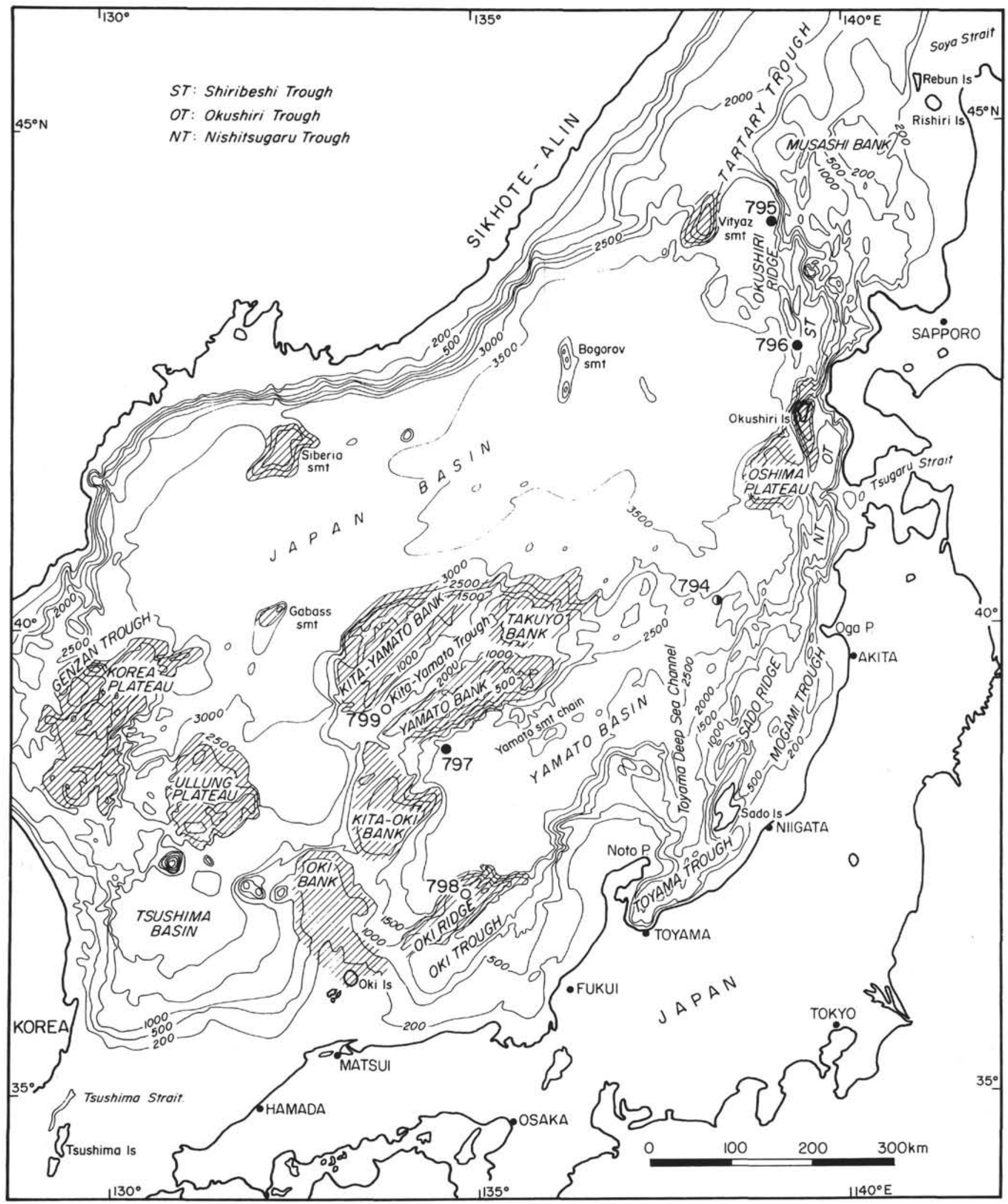

Figure 1. Bathymetry of the Japan Sea, showing the ODP Leg 127 and 128 site locations (solid and open circles, respectively). Drilling occurred at Site 794 on both legs. Basement was encountered only at Sites 794, 795, and 797. The sites form an approximate north-south transect from the northern Japan Basin (Site 795) to the Oki Ridge (Site 798). (Adapted from Tamaki, 1987.) 


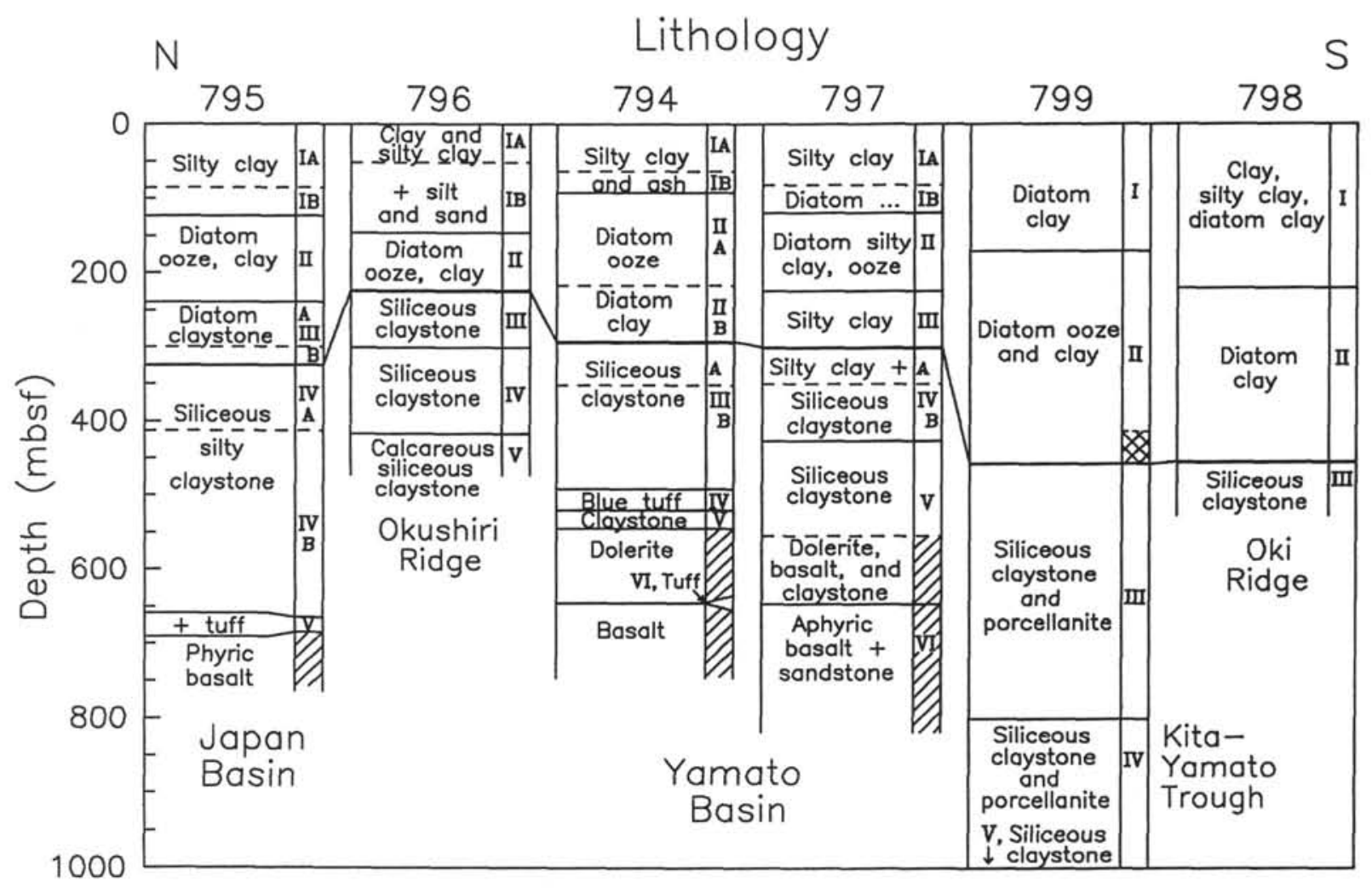

Figure 2. The major lithology for the Leg 127 and 128 sites. The opal-A/opal-CT boundary is shown as a bold line in the lithologic columns and connected from site to site. The first appearance of opal-CT to the disappearance of diatoms occurs across a broad zone at Site 799 (cross-hatched). Igneous units are shown hatched. (Adapted from Ingle, Suyehiro, von Breymann, et al., 1990; Tamaki, Pisciotto, Allan, et al., 1990.)

volume; Nobes et al., chapter 1, this volume), the interbedding of igneous rocks with sedimentary units, and the high degree of alteration in the igneous sections. Because the other physical properties can be expressed as functions of the porosity, the porosity to a large extent characterizes the physical-property variations observed across the Japan Sea sites (Fig. 3).

The physical properties are dominated by three features, as mentioned earlier: the opal-A to opal-CT transition, which is less marked at Site 796, for reasons outlined previously, and at Site 798; the high porosity of the sediments above the opal-A/opal-CT boundary; and, at the basement sites, the interbedding of igneous and sedimentary units. The high porosity of the upper sediments is easily explained by the open cellular nature of the diatoms (Pls. 1 and 2; and, e.g., Hempel et al., 1989), which have significant internal porosity. Marsters and Christian (1990) suggested that diatoms and diatomaceous fragments have well-connected pore spaces that can provide a drainage path in otherwise impermeable sediments. High porosity persists to depths of 300 and more meters below seafloor (mbsf), as has been observed before (e.g., Lee, 1973; Pittenger et al., 1989; Lee et al., 1990), and the correlation of high porosity with increased silica content in particular has been noted (Pittenger et al., 1989; Bryant and Rack, 1990; Taylor, 1991). The porosity reaches a maximum at about $100 \mathrm{~m}$ above the opal-A/opal-CT boundary, where the diatom fraction is also maximal.

Laboratory tests indicate that the sediments are generally slightly underconsolidated, with an increasing degree of underconsolidation with depth (e.g., Holler, this volume), an observation that at first glance appears to be at odds with some previous work (e.g., Lee et al., 1990; Bryant and Rack, 1990) and in agreement with others (e.g., Pittenger et al., 1989). In general, however, sediments rich in biogenic silica are underconsolidated, but other factors such as the rate of sedimentation can play an important role. Bryant and Rack attributed the overconsolidation of the high-porosity Weddell Sea sediments to the strong microfabric formed by the diatomaceous, calcareous, and clay particles, though the low rate of sedimentation (Barker, Kennett, et al., 1988) will affect the degree of consolidation. Lee et al. (1990) suggested that the overconsolidation of sediments on the Peru continental margin is attributable to diagenesis or to particle bonding by organic matter. Pittenger et al. (1989) observed that although the sediments of the Vøring Plateau are generally overconsolidated, there is a trend of increasing degree of underconsolidation in the interval with the highest silica content. Hempel et al. (1989) thus concluded that the silica-rich sediments are significantly underconsolidated.

The properties of the uppermost sediments are highly variable, possibly even cyclic (Föllmi et al., this volume). Cyclic sedimentation has been observed in a number of areas, and is most commonly attributed to the effects of paleoclimatic cyclicity (e.g., Ingle, Suyehiro, von Breymann, et al., 1990). The sediments of Site 798 certainly show signs of cyclicity, but there is evidence for the presence of turbidites as a result of tectonic activity at, for example, Site 797. Nonetheless, some distinct features can be traced across much of the Japan Sea (Fig. 4). These beds give rise to the observed sequence of stratified seismic reflectors in the upper sediments (Tamaki, Pisciotto, Allan, et al., 1990; Ingle, Suyehiro, von Breymann, et al., 1990). The diatomaceous sediments tend to exhibit less bedding and are seismically relatively transparent.

The physical properties change markedly as a result of the transformation of opal-A to opal-CT (Nobes et al., chapter 1, this volume; Kuramoto et al., this volume). The porosity, in particular, decreases sharply. This is especially noticeable at Sites 794 and 797, which are quite similar, and Sites 795 and 799 , where the porosity drops quite sharply before returning to more moderate values. We do not see as dramatic a change in the physical properties at Site 798, but the data 


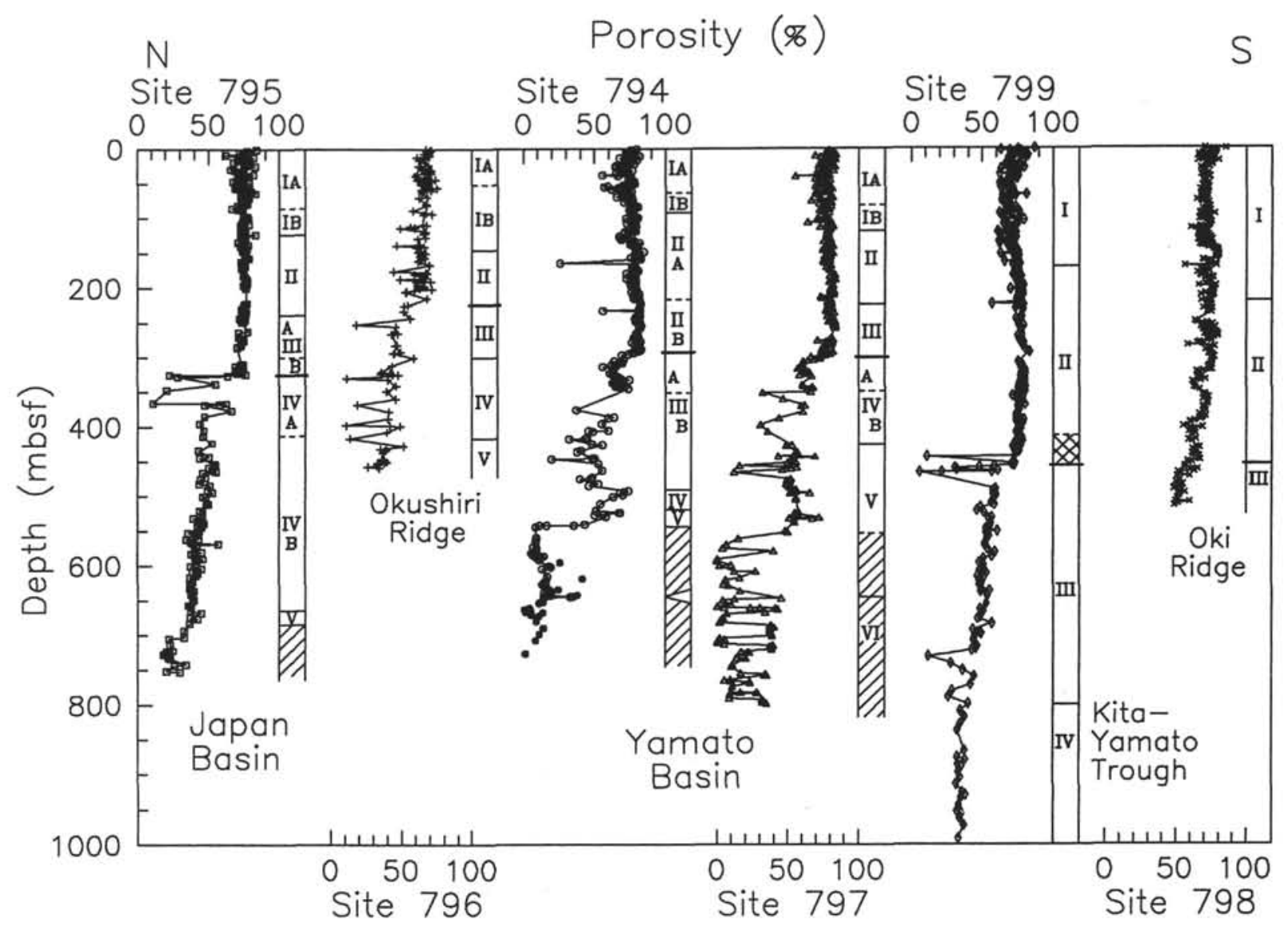

Figure 3. North-south profile of porosity from the northern Japan Sea (Site 795) to Oki Ridge (Site 798). The opal-A to opal-CT transition can be clearly seen as a sharp transition from higher to lower porosity. Note the similarity of the profiles from Sites 794 and 797 . As for Figure 2, the opal-A/opal-CT boundaries are shown as bold lines, the opal-A to opal-CT transition zone at Site 799 is shown cross-hatched, and the igneous units are shown hatched. This convention is also used in Figures 5, 6, 8, and 11. The Hole 794D (Leg 128) data are shown as solid symbols. The same symbols are used for each site in all of the figures.

do not extend much beyond the opal-A/opal-CT boundary. We note, in passing, that both of the rise sites, 796 and 798 , have more smoothly varying physical properties vs. depth than do the other sites and do not exhibit diagenetic transitions that are as sharp and distinct as at the other sites. The Okushiri Ridge (Site 796) has been uplifted recently and so may not be in equilibrium. Silica diagenesis is discussed in more detail in a separate section.

The transition to basement is quite distinct at Sites 794 and 797, and less so at Site 795. The upper igneous units at Site 795 are brecciated, and thus have much higher porosities than other igneous units. Site 794 has only a few sedimentary units interbedded with the igneous rocks, and this is reflected in the simpler pattern observed in the physical properties. The numerous interbedded units at Site 797 give rise to a complex pattern of low and moderate porosities and related high and moderate densities and acoustic velocities. The interbedded sequence gives rise to a strongly reflective seismic section (Tamaki, Pisciotto, Allan, et al., 1990). The effects of the interbedding and of the igneous alteration are discussed in detail later.

\section{DENSITY, VELOCITY, AND THERMAL CONDUCTIVITY}

The other physical properties reflect largely the variation in the porosity. The wet-bulk density, acoustic velocity, and thermal conductivity, in particular, mirror the porosity, reaching minimum values where the porosity is maximum and vice versa. The grain properties come into play as well, but the effects of porosity are dominant, especially in the sediment column. Thus, the opal-A/opal-CT boundary has a marked impact on the physical properties because of the associated decrease in porosity, and igneous alteration tends to increase the presence of hydrous minerals and secondarily the porosity as well. We will discuss the density, velocity, and thermal conductivity in turn.

\section{Wet-Bulk and Grain Densities}

The wet-bulk density (Fig. 5) illustrates most of the points introduced previously, as it essentially mirrors the porosity. The opalA/opal-CT boundary is a major boundary, and the high density of the basement rocks is apparent. The grain density (Fig. 6) has a high degree of variability above the opal-A/opal-CT boundary, especially in the uppermost units. The grain density reflects the varying clay and diatom contents; diatoms tend to have low grain densities, which theoretically can be lower than $2 \mathrm{~g} / \mathrm{cm}^{3}$ (e.g., Johnston and Olhoeft, 1984), whereas clay minerals have densities ranging as high as $2.8 \mathrm{~g} / \mathrm{cm}^{3}$ or more (Johnston and Olhoeft, 1984). This variability is in part exhibited in the dark-light "cyclic" bedding observed at most sites; the sediment cyclicity is discussed elsewhere (Föllmi et al., this volume).

The wet-bulk and grain densities reach their minimum values, which are correlated with the greatest diatom contents and associated maximum porosities, across a broad zone about $100 \mathrm{~m}$ above the opal-A/opal-CT transition. The wet-bulk density minimum is attributable both to the porosity maximum and to the grain density minimum. The grain density 


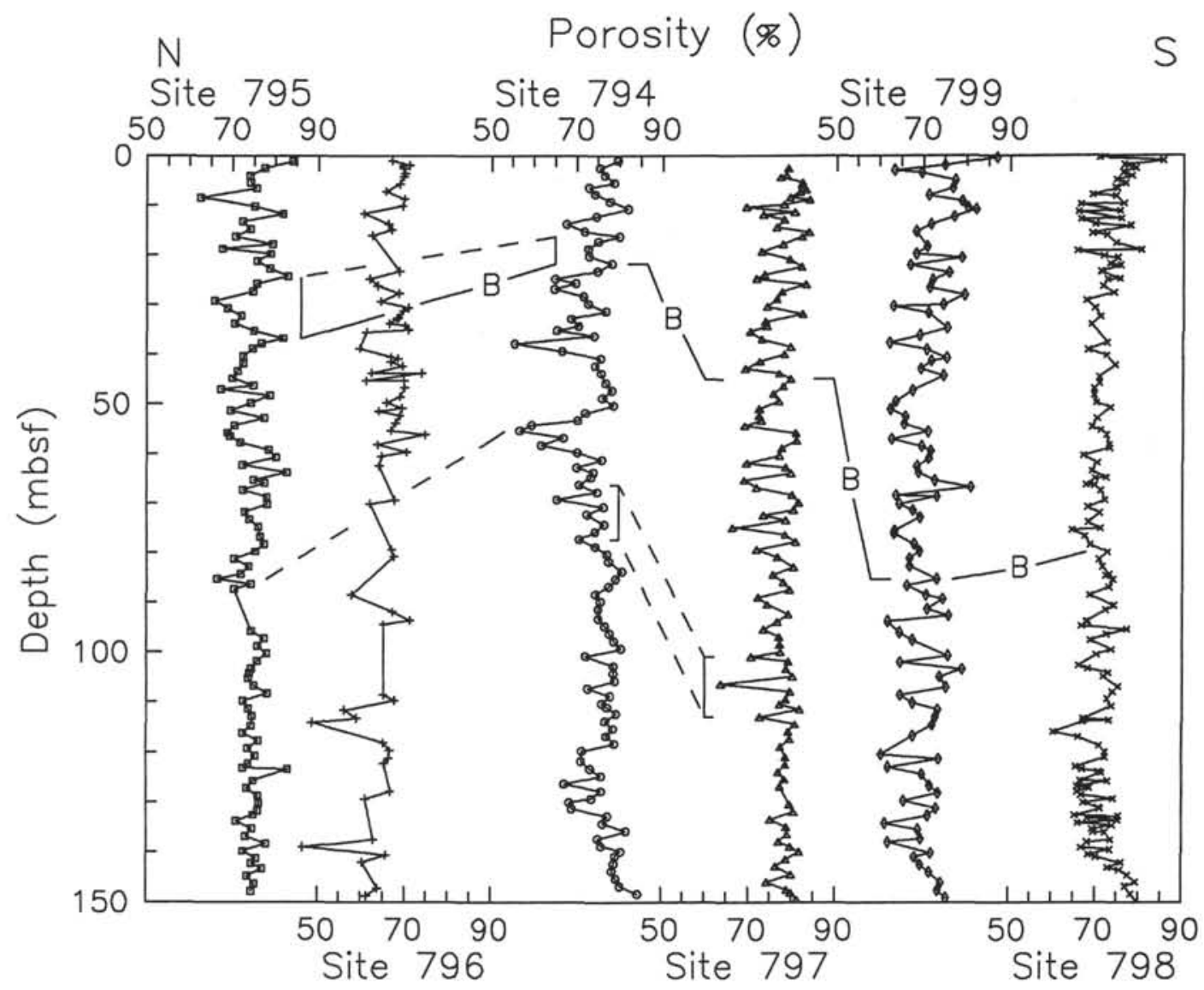

Figure 4. Detailed porosity profiles for the upper $150 \mathrm{~m}$ of the sediment columns, showing some approximate correlations from site to site. The solid lines, labeled "B," show the approximate location of the Brunhes/Matuyama boundary. The lower dashed lines show approximate correlations between Sites 794 and 795 (to the left), and between Sites 794 and 797 (center). Although there are similarities, exact correlations are complicated by the different sedimentation rates and individual site settings.

is greater in the deeper, more consolidated sections below the opalA/opal-CT boundary (Fig. 6), where the dissolution of opal-A and precipitation of opal-CT give rise both to a slightly higher grain density and to lower porosity (Fig. 2). The grain density is maximal in the igneous samples.

The influence of the grain density can be seen by plotting the wet-bulk density and grain density vs. porosity (Fig. 7). The wetbulk density, $\rho_{b}$ is related to the porosity, $\phi$, through a simple mixing law, as

$$
\rho_{b}=\rho_{w} \phi+\rho_{g}(1-\phi),
$$

where $\rho_{\mathrm{w}}$ is the density of seawater, and $\rho_{\mathrm{g}}$ is the grain density. The wet-bulk density should thus follow a line connecting the minimum (seawater) density at $100 \%$ porosity to a given maximum (grain) density at $0 \%$. The wet-bulk density data cross the mixing lines from lower values at high porosities to higher values at low porosities (Fig. 7A), illustrating the effect of the increasing grain density at depths below the opal-A/opal-CT boundary, where the porosity markedly decreases. The increase in grain density is explicitly illustrated when grain density is plotted vs. porosity (Fig. 7B). As mentioned earlier, the grain density is widely scattered at high porosities, a consequence of the variable diatom and clay contents. There is, nonetheless, a trend of increasing grain density with decreasing porosity. Hempel et al. (1989) observed a similar pattern, which they explicitly ascribed to the variation in the biogenic silica content.
The highest grain densities are obtained in the least altered, lowest porosity igneous units.

\section{Acoustic Velocity}

The acoustic velocity (Fig. 8) has the greatest range in values, and much of the detail in the sediments is not apparent when plotted at full scale. In addition, neither $P$-wave logger nor Hamilton frame acoustic velocities could be obtained from the cores recovered with the extended core barrel (XCB) because of the inherent core disturbance (e.g., Tamaki, Pisciotto, Allan, et al., 1990; Wetzel et al., 1990). This data gap can be covered if sonic velocity data are available from downhole logging, but such data records are often not present. At Site 795 , for example, technical problems prevented any logging below about 200 mbsf (Fig. 8; Tamaki, Pisciotto, Allan, et al., 1990). When such data are available, there can be imperfect agreement between the laboratory and logging velocities. The laboratory and logging mean velocity and the velocity variability may be in general agreement over a given interval, but the records may be misaligned. Sediments with chert layers, as in the case of the Japan Sea sites, commonly have poor core recovery, with large gaps, and then there are problems in assigning a correct depth to a core sample, so that the laboratory and logging velocity measurements at a specific depth may not agree. At Sites 794 and 797, for example, the general forms of the laboratory and logging velocities are similar, but the peaks are misaligned (Fig. 9). In addition, the sonic log yields an average velocity 


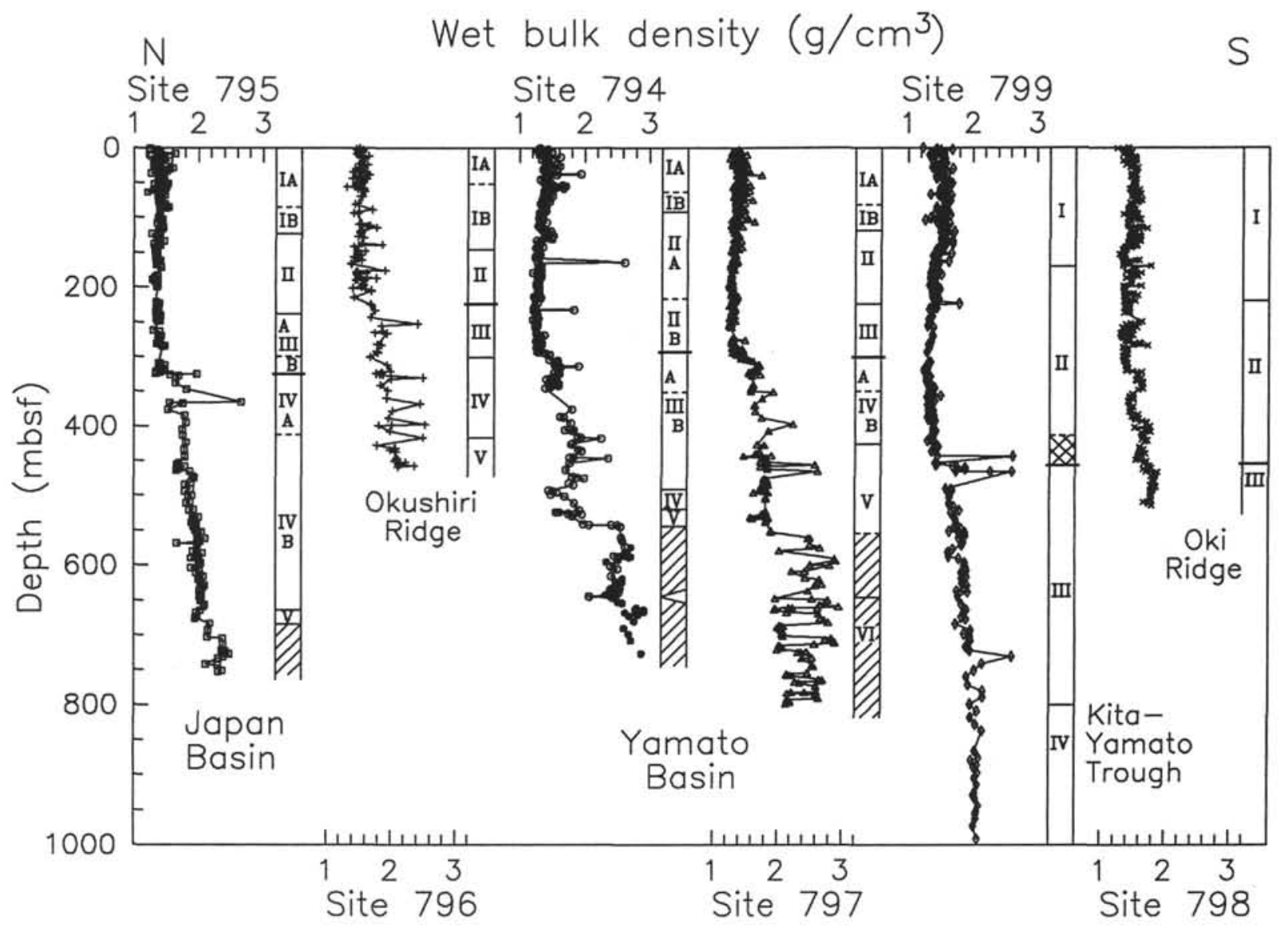

Figure 5. North-south profile of wet-bulk density from the northern Japan Sea (Site 795) to Oki Ridge (Site 798). Again, the opal-A to opal-CT transition shows as a sharp transition. Note the similarity of the profiles for Sites 794 and 797 and those for Sites 795 and 799.

over an interval of 2.4 to $3.6 \mathrm{~m}$ (e.g., Tamaki, Pisciotto, Allan, et al., 1990), whereas the laboratory velocity is obtained from a discrete sample that represents a small interval of a few centimeters. The laboratory velocity can therefore be significantly higher or lower than the sonic velocity (e.g., Fig. 9). Finally, the shipboard laboratory velocity is taken under ambient room conditions, and numerous workers have suggested that laboratory data must be corrected for mechanical rebound effects (e.g., Hamilton, 1976; Fulthorpe et al., 1989). Recent work has questioned the need for corrections at all, noting generally good agreement between laboratory and logging data (Nobes, Mwenifumbo, et al., 1991), though a hydraulic correction for the change in seawater density and velocity may be needed (Urmos et al., in press), especially in unconsolidated oozes. Discrepancies between laboratory and logging data are most likely the result of core disturbance (Tamaki, Pisciotto, Allan, et al., 1990; Wetzel et al., 1990; Nobes, Mwenifumbo, et al., 1991; Urmos et al., in press).

As for the wet-bulk density, the velocity is dependent on the porosity (Fig. 10), but the form of the dependence is not as simple. For sediments, the velocity decreases with an increase in the porosity as (Nobes, 1989)

$$
\frac{1}{V_{P}}=\frac{\phi}{V_{W}}+\frac{(1-\phi)}{V_{T A}}
$$

where $\phi$ is the porosity, $V_{W}$ represents the velocity of a slurry with no shear strength, and $V_{T A}$ is the time-average velocity of a rigid mixture in which the traveltime (inverse velocity) is the average of the traveltimes across the individual fluid and solid components (Wyllie et al., 1956). For igneous rocks, the time-average model is more representative, in which case:

$$
\frac{1}{V_{P}}=\frac{\varphi}{V_{f}}+\frac{(1-\varphi)}{V_{g}},
$$

where $V_{f}$ is the fluid (seawater) velocity, about $1500 \mathrm{~m} / \mathrm{s}$, and $V_{g}$ is the grain velocity. Crustal grain velocities range from a low of $3400 \mathrm{~m} / \mathrm{s}$ for shale to $6500 \mathrm{~m} / \mathrm{s}$ or more for basalts. Shale with $70 \%$ clay content has a grain velocity of about $4000 \mathrm{~m} / \mathrm{s}$, which provides an approximate lower bound on the data in Figure 10. By rearranging equation (3), we may in principle obtain the grain velocity from the porosity and the acoustic velocity. It may then be possible to use the grain velocity combined with the grain density to examine the effects of alteration and mineralogy on the grain physical properties.

There appears to be a gap in the velocity vs. porosity data at about $60 \%$ porosity (Fig. 10), which on closer examination occurs at the opal-A to opal-CT transition (Nobes et al., chapter 1, this volume). The velocities in the high-porosity sediments above the transition change very little, and are almost constant, whereas the velocities in the sediments below the transition tend to follow the model curves. This critical point has been observed in at least one other study (Chen and Nur, 1991; Nur et al., 1991), where the velocity was found to be almost constant above a critical porosity and followed a smoothly varying profile below this value. This suggests that there is a certain degree of contact or consolidation required before the acoustic velocity changes in proportion to the amount of solid (grain) material present.

\section{Thermal Conductivity}

The thermal conductivity (Fig. 11) follows much the same pattern displayed by the other physical properties, such as the wet-bulk 


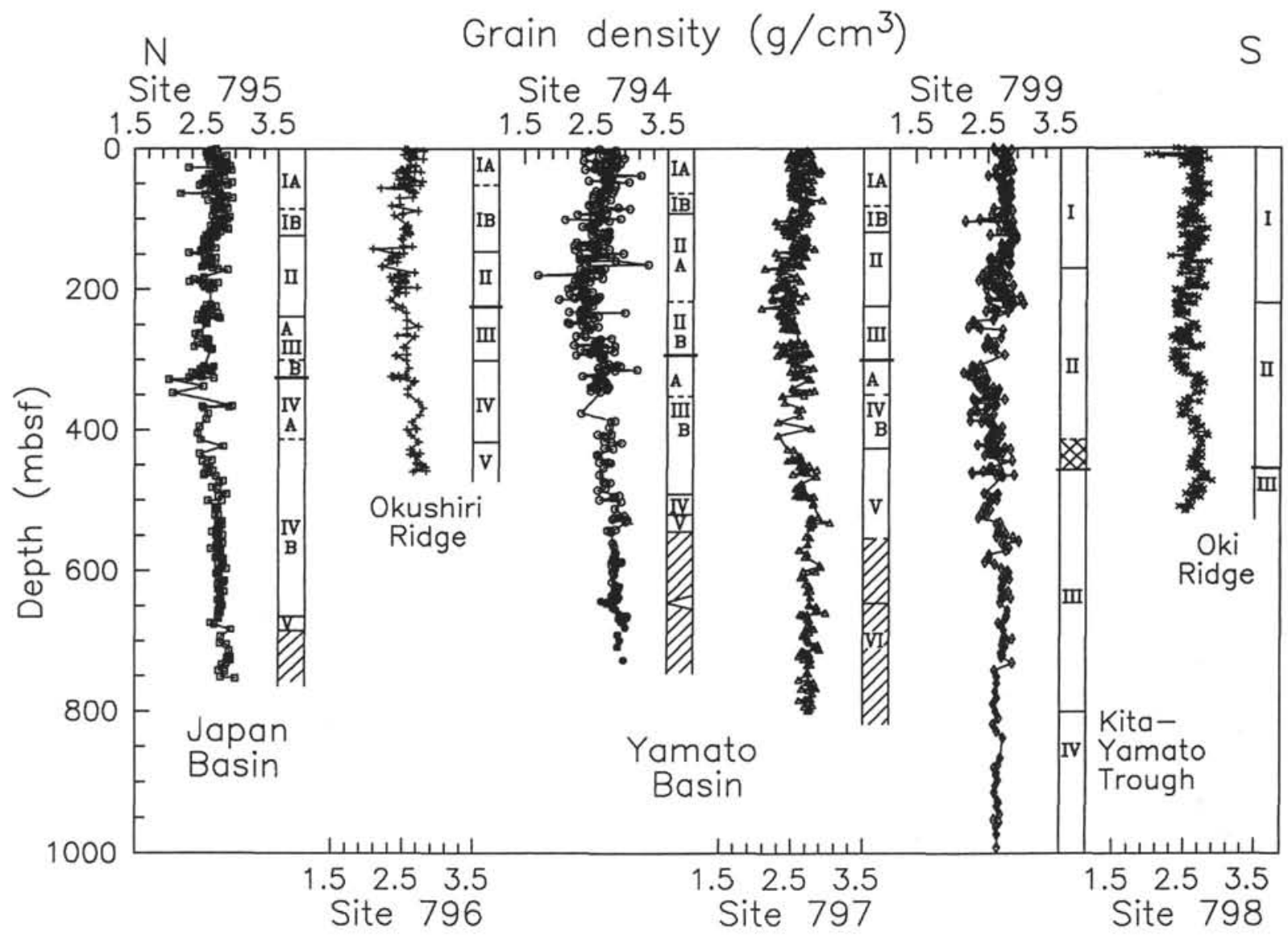

Figure 6. North-south profile of grain density from the northern Japan Sea (Site 795) to Oki Ridge (Site 798). The grain density is generally low and highly variable above the opal-A/opal-CT diagenetic boundary. The grain density at all sites reaches minimum values in the upper section about $100 \mathrm{~m}$ above the opal-A/opal-CT boundaries.

density. It is also important for the understanding of the thermal state of the Japan Sea (Langseth and Tamaki, this volume). There are problems in obtaining good thermal conductivity data from XCB cores (e.g., Tamaki, Pisciotto, Allan, et al., 1990), because the cores can be biscuited and disturbed and insertion of a needle probe may crack the sediment. The measured thermal conductivities will then be lower than the actual values. Values that are obviously unreliable have not been used.

The thermal conductivity in general follows a geometric mean law (e.g., Woodside and Messmer, 1961; Henderson and Davis, 1983):

or

$$
k=k_{f}^{\phi} k_{g}^{(1-\phi)}
$$

$$
\log k=\phi \log k_{f}+(1-\phi) \log k_{g}
$$

where $k_{f}$ is the seawater thermal conductivity, about $0.6 \mathrm{~W} / \mathrm{m}-\mathrm{K}$, and $k_{g}$ is the grain thermal conductivity. The geometric mean mixing law can be extended to three or more components (Lei, 1991), as

$$
\log \mathrm{k}=\sum f_{i} \log k_{i}
$$

where $f_{i}$ is the fraction of component $i$ present with thermal conductivity $k_{i}$. Although there is some experimental support for equation (4), the multicomponent system of equation (5) has not been tested.

We can compare the simple geometric mean law, equation (4), with the measured thermal conductivities (Fig. 12); there is good agreement. The igneous units have an apparent grain thermal conductivity that lies between 1.5 and $2.0 \mathrm{~W} / \mathrm{m}-\mathrm{K}$, which is consistent with estimates of about $1.7 \mathrm{~W} / \mathrm{m}-\mathrm{K}$ (e.g., Hyndman et al., 1977) and with the range of previously observed values of 1.44 to $2.12 \mathrm{~W} / \mathrm{m}-\mathrm{K}$ (e.g., Hyndman et al., 1979). The sediment thermal conductivities cluster about the curve for a grain thermal conductivity of $2.5 \mathrm{~W} / \mathrm{m}-\mathrm{K}$, a reasonable value for a mixture of silt, clay, and diatoms.

\section{SILICA DIAGENESIS}

Unlike many other areas, the opal-A/opal-CT diagenetic boundary is a major thermal and seismic horizon in the Japan Sea (Kuramoto et al., this volume; Langseth and Tamaki, this volume), and the widespread effects of the diagenesis are recorded in the sediment physical properties (Nobes et al., chapter 1, this volume). The opal-A to opal-CT transition occurs at roughly the same age, $6 \pm 2 \mathrm{Ma}$, and temperature, $42^{\circ} \pm 5^{\circ} \mathrm{C}$, for the Leg 127 and 128 sites (Fig. 13). The consistency of the opal-A/opal-CT boundary allows the thermal evolution of the sediments to be examined, and an estimate of the activation energy of the diagenetic reaction is in agreement with experimental results (Langseth and Tamaki, this volume).

One feature of the diagenesis is the generally sharp transition from opal-A to opal-CT and from opal-CT to quartz, which has been observed not only in the Japan Sea, but elsewhere (e.g., Pisciotto, 1981a, 1981b; Kastner and Gieskes, 1983; Tada and Iijima, 1983). The physical properties change markedly, as mentioned previously. However, depending on how one defines the beginning and end of the diagenetic transitions, the thickness of the zones can range from $10 \mathrm{~m}$ or more to $1 \mathrm{~m}$ or less (Nobes et al., chapter 1 , this volume). Going downhole, diagenesis is progressive, and opal-A and opal-CT 

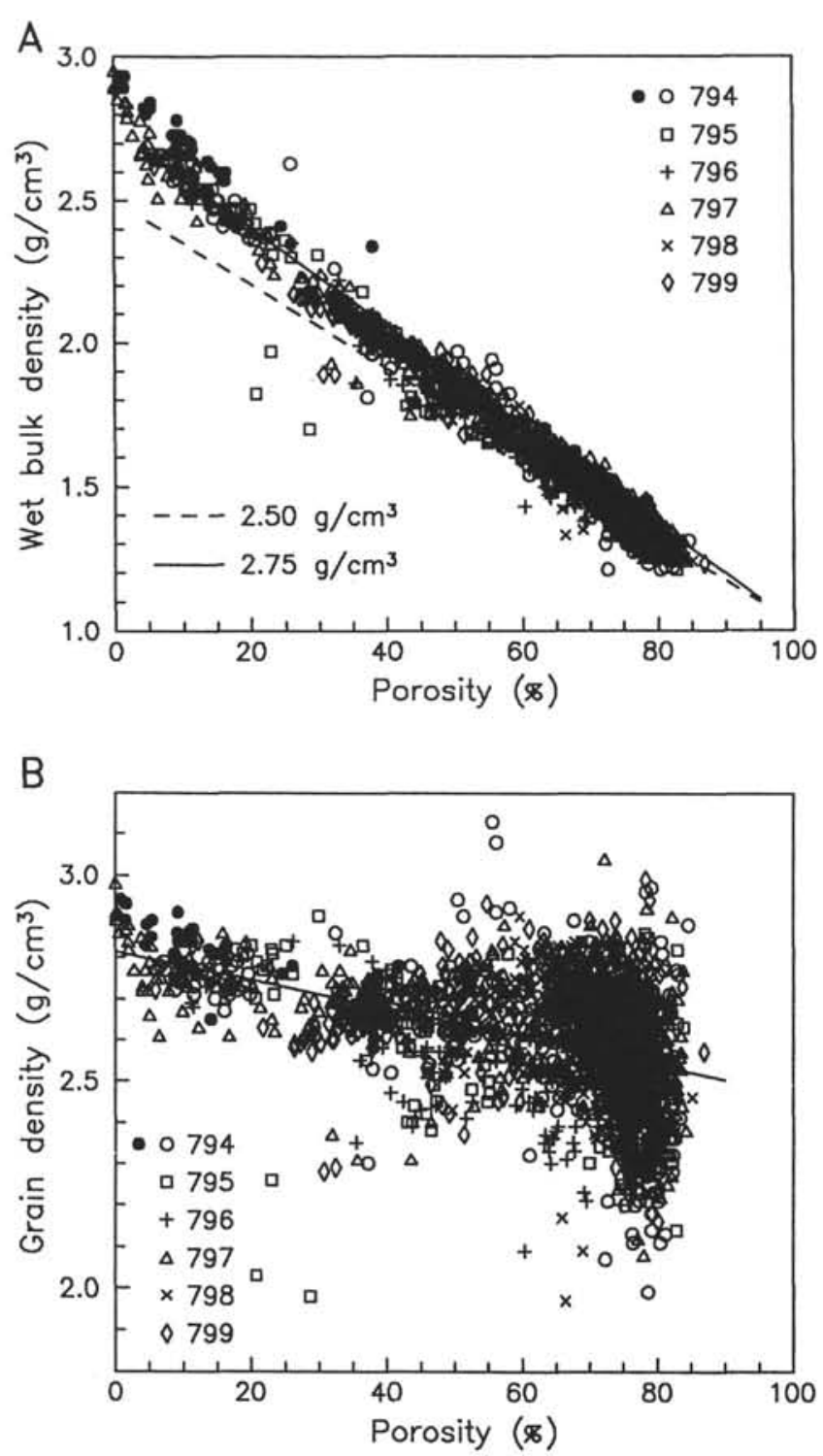

Figure 7. Wet-bulk density (A) and grain density (B) vs. porosity for all sites and lithologies. Note that the general trend of the wet-bulk density data crosses the theoretical mixing lines for grain densities of $2.5 \mathrm{~g} / \mathrm{cm}^{3}$ (dashed) and $2.75 \mathrm{~g} / \mathrm{cm}^{3}$ (solid), suggesting that grain density increases as porosity decreases. The grain density data, although widely scattered, appear to follow such a trend, as shown by the best-fit linear trend for Site 797, which has the greatest range of rock types and porosities.

generally coexist over some interval; opal-CT and quartz similarly overlap (Pisciotto, 1981a, 1981b). At each transition, there is a significant reduction in porosity, which has been observed elsewhere (Isaacs et al., 1983; Tada, 1991). The opal-CT to quartz boundary is particularly sharp, less than $1 \mathrm{~m}$ thick. The opal-A to opal-CT transition, on the other hand, can be defined in a number of ways, for example on the basis of the first appearance of opal-CT and the last occurrence of undissolved diatoms. Zeolites, such as clinoptilolite (PI. 3), are common (Nobes et al., chapter 1, this volume) and are byproducts of the diagenetic transition from opal-A to opal-CT, especially in the presence of clay minerals (e.g., Kastner et al., 1977; Kastner and Gieskes, 1983).

The gamma-ray attenuation (GRAPE) density vs. distance from the opal-A/opal-CT boundary illustrates some of the difficulties in establishing the thickness of the transition zone, as is shown for Sites 794 and 797 (Fig. 14). There is a noticeable increase in the density starting about $10 \mathrm{~m}$ above the boundary. About $1 \mathrm{~m}$ above the boundary, the increase accelerates, and a relatively constant density is reached just below the boundary. The other laboratory and logging physical properties display similar features (Nobes et al., chapter 1, this volume). We can thus define the opal-A to opal-CT transition either as the zone where the physical properties change most rapidly or where the properties exhibit a recognizable trend. The latter is in better agreement with other indicators, such as X-ray diffraction measurements, which reveal the presence of incipient opal-CT well above the opal-A/opal-CT boundary (Nobes et al., chapter 1, this volume; Murray et al., chapter 39, this volume).

\section{IGNEOUS PHYSICAL PROPERTIES}

The igneous rocks recovered on Leg 127 were generally highly altered, so much so that in many cases the original minerals had been completely replaced (Tamaki, Pisciotto, Allan, et al., 1990). The igneous rocks are highly fractured as well, and the fractures appear to be preferentially oriented, because the regional acoustic velocity is anisotropic (Hirata et al., this volume). Although preliminary analyses suggest that there may be a measurable effect of the alteration on various properties, including the physical properties (Tamaki, Pisciotto, Allan, et al., 1990), only cursory and inconclusive comparative analyses have been carried out. The results of an initial study are presented here, but a more complete report awaits further analysis.

Qualitative comparisons between the degree of igneous alteration and the rock physical properties have been carried out by a number of researchers, generally using downhole logging data (see, e.g., Becker, 1990). Broglia and Ellis (1990) showed, for example, that the porosity and density correction logs decrease, and the formation density increases, as the degree of alteration decreases. The alteration is expressed either as an "alteration index" or through the concentrations of hydrous minerals. The loss on ignition (LOI) is a measure of the hydrous mineral content (e.g., Peirce, Weissel, et al., 1989; Saunders et al., 1991), particularly clays and zeolites, which generally increase the porosity as well. Thus, we expect a correlation between the physical properties and the LOI.

Moos et al. (1990) examined the relationship between the formation compressional $\left(V_{P}\right)$ and shear $\left(V_{S}\right)$ velocities for massive basalt units, pillow basalts, and basaltic breccia, but have not explicitly compared physical properties with any quantitative chemical measurements. The $V_{P} / V_{S}$ ratio may be diagnostic of the degree of alteration. Smith and Vine $(1987,1989)$ have shown that the grain density and seismic velocities decrease as the degree of alteration, in particular serpentinization, increases.

The most extensive data sets, using primarily downhole logging measurements, have been obtained from Hole 504B (e.g., Pezard et al., 1989, 1991; Pezard and Anderson, 1989; Jarrard and Broglia, 1991) and from the Atlantis II Fracture Zone (Shipboard Scientific Party, 1989). There is a correlation between the apparent formation factor, the ratio between the formation and pore-fluid resistivities, and the cation exchange capacity, or CEC (Pezard et al., 1989; Pezard and Anderson, 1989; Pezard, 1990). The CEC is a measure of the chemical activity of clay-rich layers and may thus indicate the presence of clay alteration minerals. Iturrino et al. (1991) noted a correlation between the number of veins and cracks with the degree of alteration, and the subsequent replacement of olivine with magnetite and talc serves to lower the densities and the acoustic velocity. Jarrard and Broglia (1991) found that there is a correlation of high porosities and long sonic log transit times (i.e., low velocities) with the degree of alteration, which has been divided into classes as slightly, moderately, or highly altered. Goldberg, Broglia, and Becker (1991) found, as we have in our preliminary work, that there is a correlation between the physical properties and the presence of hydrous minerals, and Goldberg, Badri, and Wepfer (1991) suggested that the attenuation of compressional waves may be diagnostic of the degree of alteration. 


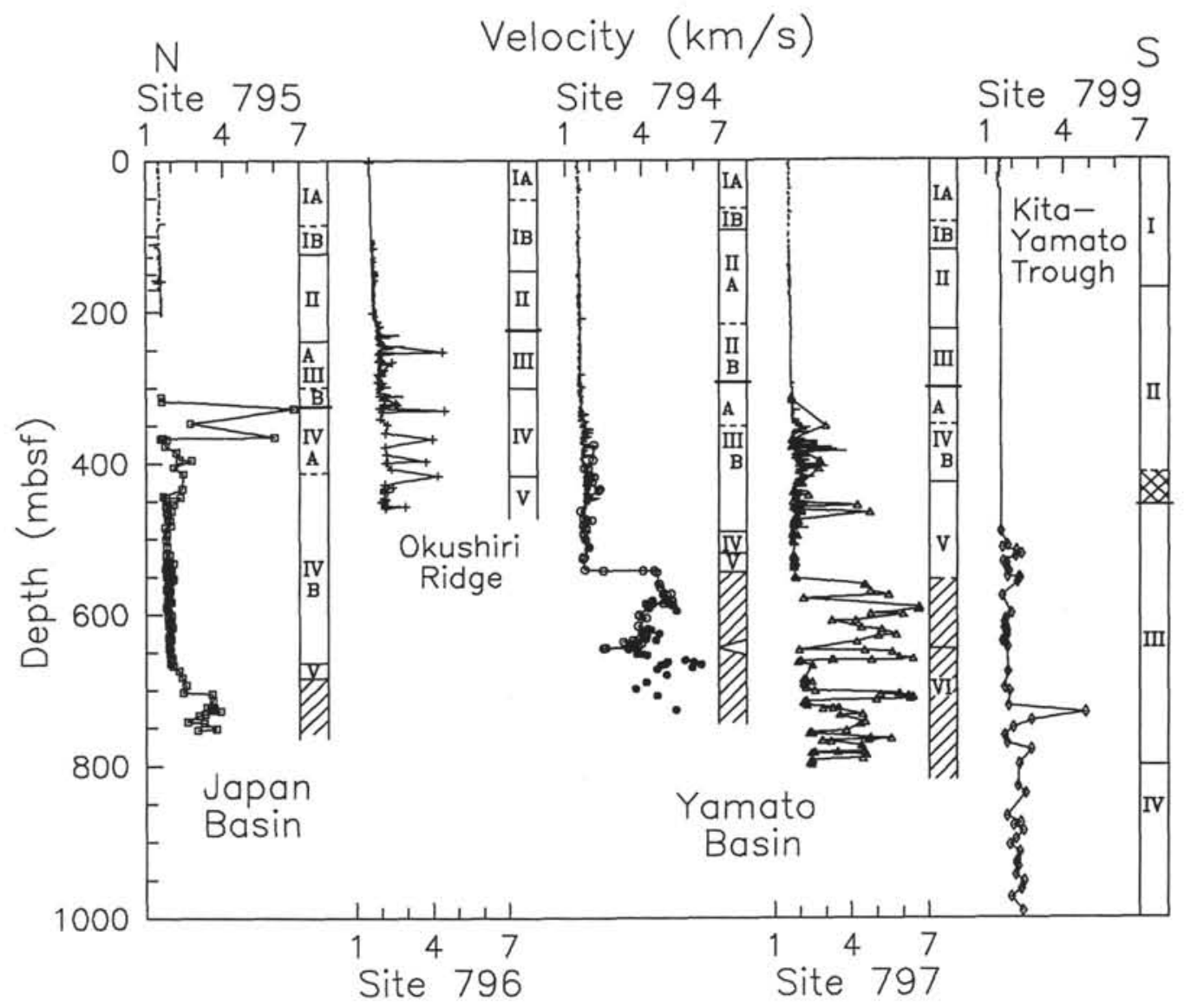

Figure 8. North-south profile of acoustic velocity from the northern Japan Sea (Site 795) to Oki Ridge (Site 798). If complete data coverage across the boundary is available, the opal-A to opal-CT transition appears as a sharp transition from lower to higher velocity.

Iturrino et al. (1991) also noted the effects of phyllosilicates and found that the velocity and density appear to follow Birch's (1961) law.

Unfortunately, downhole logging runs were generally unsuccessful in the igneous units of Leg 127, and we must compare the physical-property and igneous geochemistry shipboard data sets. Few such comparisons have been attempted previously, primarily because the physical-property and igneous petrology data are usually gathered from different sample locations, and thus can not be directly compared. An effort was made, as much as possible, to gather adjacent samples for igneous petrology thin section and X-ray fluorescence (XRF) analyses and for physical-property measurements. In some cases, physical-property sample residues have been used for thin section and/or XRF analyses.

The igneous units encountered at Sites 794 and 797 are interbedded with sediments, as illustrated in Figure 15 and Plate 4. The units at Site 795, although not apparently interbedded, are highly altered, brecciated basalts (Pl. 5), with associated high porosities. At Sites 794 and 797 , on the other hand, the interbedding gives rise to the strongly reflective seismic section observed (Tamaki, Pisciotto, Allan, et al., 1990). The interbedded sediments have lower porosities than the sediments above the igneous units, and the igneous rocks are generally highly altered. The interbedding at Site 797 , in particular, produces complex physical-property profiles.

The formation properties vary with porosity in a systematic manner, as discussed earlier. When the igneous sample densities and velocities are plotted vs. the corresponding porosities (Figs. 16A and $16 \mathrm{~B}$, respectively), we can see, as before, that the data tend to cross the lines representing constant grain densities and velocities. Site 797 has the greatest range in porosities, and the best-fitting linear trend line for Site 797 (shown dashed in Fig. 16) clearly crosses the model curves from high grain values at low porosities to low values at high porosities. We emphasize that more detailed analyses are required, and specific regression parameters will not be discussed.

The porosity and LOI tend to increase together (Fig. 17). Because the formation properties are dependent on the porosity, the acoustic velocity and wet-bulk density will decrease as the LOI increases, an observation that is consistent with the results of, for example, Smith and Vine $(1987,1989)$. If the LOI is indicative of the amount of hydrous minerals that are present, then the apparent porosity can be greater if some of the loosely bound water in the hydrous minerals escapes during the normal drying process for the determination of the index properties.

When we examine the variation of the grain density and velocity vs. LOI (Fig. 18), we see a systematic decrease in the grain density (Fig. 18A), and to a lesser extent in the grain velocity (Fig. 18B), as LOI increases. The grain densities for Sites 794 (solid line, Fig. 18A) and 797 (dashed line) follow clear trends. The grain velocity is much more scattered, but a weak trend is still apparent for the Site 794 data. In other words, as the degree of alteration increases and the igneous minerals are replaced by clay and zeolite minerals, the grain density and grain velocity, and by association the formation properties, decrease in a systematic way. The data are, however, too sparse at present to make more than a general observation, but this preliminary work is consistent with earlier work (e.g., Iturrino et al., 1991; Goldberg, Broglia, and Becker, 1991; Jarrard and Broglia, 1991). Additional work is required, whereby the physical and chemical variations within individual units are examined so that differences in the original mineralogy are not a factor. 

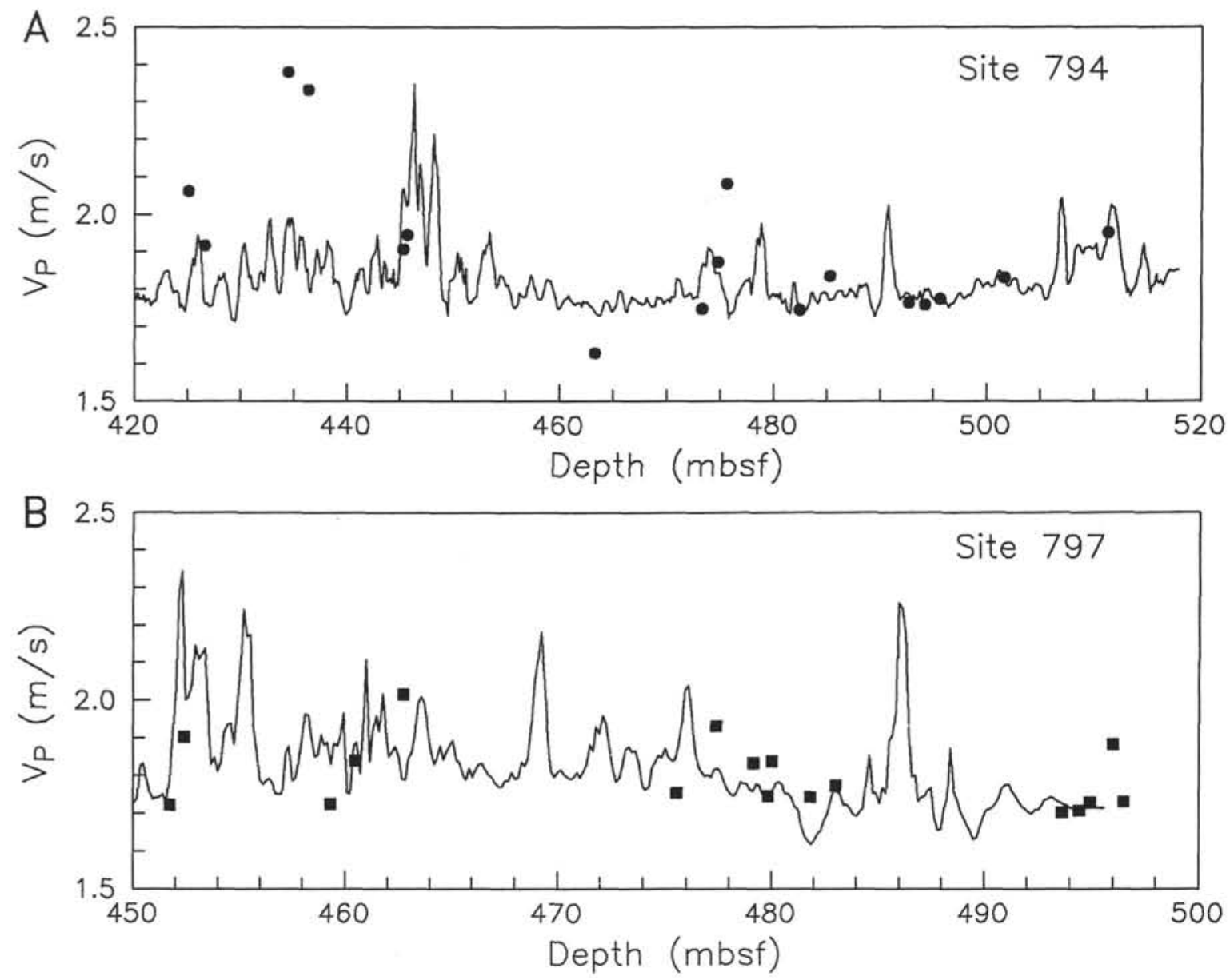

Figure 9. The laboratory acoustic velocity (solid symbols) and sonic logging velocity for a selected depth interval from (A) Site 794 and (B) Site 797. The data are in general agreement, but because of core gaps the laboratory and logging data may not be in alignment (e.g., at $475 \mathrm{mbsf}$ at Site 794 and at 460 and $476 \mathrm{mbsf}$ at Site 797). In addition, the sonic log yields an average velocity over an interval 2.4 to $3.6 \mathrm{~m}$ ( 8 to $12 \mathrm{ft}$ ) long, whereas the laboratory data are taken on discrete samples that are $2 \mathrm{~cm}$ long. The laboratory velocity can thus be significantly higher or lower than the sonic velocity, as, for example, at 430,463 , and $474 \mathrm{mbsf}$ at Site 794 .

\section{SUMMARY}

The sediment physical-property data for Legs 127 and 128 reflect the high porosities of the upper sediment columns, the lithologic variation from high clay content to high diatom content, and the diagenetic transformation from opal-A to opal-CT. The porosity reaches a maximum, and the wet-bulk and grain densities reach minima, about $100 \mathrm{~m}$ above the opal-A/opal-CT boundary. The transition from opal-A to opal-CT occurs over a relatively narrow interval, but can be delineated across a zone $10 \mathrm{~m}$ or more thick. Because of its consistency, the opal-A/opal-CT boundary is a significant seismic and thermal marker horizon across the Japan Sea.

The interbedding of igneous and sedimentary units at Site 797 and, to a lesser extent, Site 794 gives rise to strongly reflective sequences. The high degree of alteration is expressed in the physical properties. In particular, the loss on ignition is related to the presence of hydrous minerals, and the grain density and grain velocity decrease as the loss on ignition increases. Further investigation is required before any systematic variation with igneous petrology can be identified.

\section{ACKNOWLEDGMENTS}

We recognize the marine technicians who assisted with the acquisition of the physical-property measurements, in particular, $\mathrm{Mr}$.
M. Simpson during Leg 127 and Mr. J. DeMorett during Leg 128. We thank Drs. Kinoshita and Taylor for their comments. DCN acknowledges the support of the Natural Science and Engineering Research Council of Canada through a Collaborative Special Projects grant.

\section{REFERENCES}

Barker, P. F., Kennett, J. P., et al., 1988. Proc. ODP, Init. Repts., 113: College Station, TX (Ocean Drilling Program).

Becker, K., 1990. Introduction to the special section on logging and downhole measurements in Deep Sea Drilling Project/Ocean Drilling Program deep crustal holes. J. Geophys. Res., 95:9149-9151.

Birch, F., 1961. The velocity of compressional waves in rocks to 10 kilobars, Part 2. J. Geophys. Res., 66:2199-2224.

Boyce, R. E., 1976. Definitions and laboratory techniques of compressional sound velocity parameters and wet-water content, wet-bulk density and porosity parameters by gravimetric and gamma-ray attenuation techniques. In Schlanger, S. O., Jackson, E. D., et al., Init. Repts. DSDP, 33: Washington (U.S. Govt. Printing Office), 931-958.

Broglia, C., and Ellis, D., 1990. Effect of alteration, formation absorption, and standoff on the response of the thermal neutron porosity log in gabbros and basalts: examples from Deep Sea Drilling Project-Ocean Drilling Program sites. J. Geophys. Res., 95:9171-9188.

Bryant, W. R., and Rack, F. R., 1990. Consolidation characteristics of Weddell Sea sediments: results of ODP Leg 113. In Barker, P. F., Kennett, J. P., et al., Proc. ODP, Sci. Results, 113: College Station, TX (Ocean Drilling Program), 211-223. 
Chen, Q., and Nur, A., 1991. Critical concentration models for the mechanical and acoustic properties of porous rocks and sediments. Eos, 72:438.

Fulthorpe, C. S., Schlanger, S. O., and Jarrard, R. D., 1989. In situ acoustic properties of pelagic carbonate sediments on the Ontong Java Plateau. J. Geophys. Res., 94:4025-4032.

Goldberg, D., Badri, M., and Wepfer, W., 1991. Ultrasonic attenuation measurements in gabbros from Hole 735B. In Von Herzen, R. P., Robinson, P. T., et al., Proc. ODP, Sci. Results, 118: College Station, TX (Ocean Drilling Program), 253-260.

Goldberg, D., Broglia, C., and Becker, K., 1991. Fracturing, alteration, and permeability: in-situ properties in Hole 735B. In Von Herzen, R. P., Robinson, P. T., et al., Proc. ODP, Sci. Results, 118: College Station, TX (Ocean Drilling Program), 261-270.

Hamilton, E. L., 1976. Variations in density and porosity with depth in deep-sea sediments. J. Sediment. Petrol., 46:280-300.

Hempel, P., Mayer, L., Taylor, E., Bohrmann, G., and Pittenger, A., 1989 The influence of biogenic silica on seismic lithostratigraphy at ODP Sites 642 and 643, Eastern Norwegian Sea. In Eldholm, O., Thiede, J., Taylor, E., et al., Proc. ODP, Sci. Results, 104: College Station, TX (Ocean Drilling Program), 941-951.

Henderson, J., and Davis, E. E., 1983. An estimate of the heat flow in the western North Atlantic at Deep Sea Drilling Project Site 534. In Sheridan, R. E., Gradstein, F. M., et al., Init. Repts. DSDP, 76: Washington (U.S. Govt. Printing Office), 719-724.

Hyndman, R. D., Christensen, N. I., and Drury, M. J., 1979. Seismic velocities, densities, electrical resistivities, porosities and thermal conductivities of core samples from boreholes into the islands of Bermuda and the Azores. In Talwani, M., Harrison, C. G., and Hayes, D. E. (Eds.), Deep Drilling Results in the Atlantic Ocean: Ocean Crust. Am. Geophys. Union, 94-112.

Hyndman, R. D., Von Herzen, R. P., Erickson, A. J., and Jolivet, J., 1977. Heat-flow measurements DSDP Leg 37. In Aumento, F., Melson, W. G., et al., Init. Repts. DSDP, 37: Washington (U.S. Govt. Printing Office), 347-362.

Ingle, J. C., Jr., Suyehiro, K., von Breymann, M. T., et al., 1990. Proc. ODP, Init. Repts., 128: College Station, TX (Ocean Drilling Program).

Isaacs, C. M., Pisciotto, K. A., and Garrison, R. E., 1983. Facies and diagenesis of the Monterey Formation, California: a summary. In Iijima, A., Hein, J. R., and Siever, R. (Eds.), Siliceous Deposits in the Pacific Region: Amsterdam (Elsevier), 247-282.

Iturrino, G. J., Christensen, N. I., Kirby, S., and Salisbury, M. H., 1991. Seismic velocities and elastic properties of oceanic gabbro rocks from Hole 735B. In Von Herzen, R. P., Robinson, P. T., et al., Proc. ODP, Sci. Results, 118: College Station, TX (Ocean Drilling Program), 227-244.

Jarrard, R. D., and Broglia, C., 1991. Geophysical properties of oceanic crust at Sites 768 and 770. In Silver, E. A., Rangin, C., von Breymann, M. T., Proc. ODP, Sci. Results, 124: College Station, TX (Ocean Drilling Program), 75-90.

Johnson, G. R., and Olhoeft, G. R., 1984. Density of rocks and minerals. In Carmichael, R. S. (Ed.), CRC Handbook of Physical Properties of Rocks (Vol. 3): Boca Raton, FL (CRC Press, Inc.), 1-38.

Kastner, M., and Gieskes, J. M., 1983. Opal-A to opal-CT transformation: a kinetic study. In Iijima, A., Hein, J. R., and Siever, R. (Eds.), Siliceous Deposits in the Pacific Region: Amsterdam (Elsevier), 211-227.

Kastner, M., Keene, J. B., and Gieskes, J. M., 1977. Diagenesis of siliceous oozes: I. Chemical controls on the rate of opal-A to opal-CT transformation - an experimental study. Geochim. Cosmochim. Acta, 41:1041-1059.

Lee, H., 1973. Measurements and estimates of engineering and other physical properties, Leg 19. In Creager, J. S., Scholl, D. W., et al., Init. Repts. DSDP, 19: Washington (U.S. Govt. Printing Office), 701-719.

Lee, H. J., Kayen, R. E., and McArthur, W. G., 1990. Consolidation, triaxial shear-strength, and index property characteristics of organic-rich sediment from the Peru continental margin: results from Leg 112. In Seuss, E., von Heune, R., et al., Proc. ODP, Sci. Results, 112: College Station, TX (Ocean Drilling Program), 639-651.

Lei, H., 1991. Variations of physical properties across Cascadia Basin [M.Sc. thesis]. Univ. of Waterloo, Waterloo, Ontario.

Marsters, J. C., and Christian, H. A., 1990. Hydraulic conductivity of diatomaceous sediment from the Peru continental margin obtained during ODP Leg 112. In Seuss, E., von Heune, R., et al., Proc. ODP, Sci. Results, 112: College Station, TX (Ocean Drilling Program), 633-638.

Moos, D., Pezard, P., and Lovell, M., 1990. Elastic wave velocities within ocean Layer 2 from sonic full waveform logs in Deep Sea Drilling Project Holes 395A, 415A, and 504B. J. Geophys. Res., 95:9189-9207.
Mumpton, F. A., and Ormsby, W. C., 1978. Morphology of zeolites in sedimentary rocks by scanning electron microscopy. In Sand, L. B., and Mumpton, F. A. (Eds.), Natural Zeolites: Oxford (Pergamon Press), $113-132$.

Nobes, D. C., 1989. A test of a simple model of the acoustic velocity in marine sediments. J. Acoust. Soc. Am., 38:525-544.

Nobes, D. C., Mienert, J., and Dirksen, G. J., 1991. Lithologic control of physical property interrelationships. In Ciesielski, P. F., Kristoffersen, Y., et al., Proc. ODP, Sci. Results, 114: College Station, TX (Ocean Drilling Program), 657-669.

Nobes, D. C., Mwenifumbo, C. J., Mienert, J., and Blangy, J.- P., 1991. The problem of porosity rebound in deep-sea sediment cores: a comparison of laboratory and in-situ physical property measurements, Site 704, Meteor Rise. In Ciesielski, P. F., Kristoffersen, Y., et al., Proc. ODP, Sci. Results, 114: College Station, TX (Ocean Drilling Program), 711-716.

Nur, A., Marion, D., and Yin, H., 1991. Wave velocities in sediments. In Hovem, J. M., Richardson, M. D., and Stoll, R. D. (Eds.), Shear Waves in Marine Sediments: Dordrecht (Kluwer Academic), 131-140.

Peirce, J., Weissel, J., et al., 1989. Proc. ODP, Init. Repts., 121: College Station, TX (Ocean Drilling Program).

Pezard, P., 1990. Electrical properties of mid-ocean ridge basalt and implications for the structure of the upper oceanic crust in Hole 504B. J. Geophys. Res., 95:9237-9264.

Pezard, P., and Anderson, R. N., 1989. Morphology and alteration of the upper oceanic crust from in-situ electrical experiments in DSDP/ODP Hole 504B. In Becker, K., Sakai, H., et al., Proc. ODP, Sci. Results, 111: College Station, TX (Ocean Drilling Program), 133-146.

Pezard, P., Howard, J. J., and Goldberg, D., 1991. Electrical conduction in oceanic gabbros, Hole 735B, Southwest Indian Ridge. In Von Herzen, R. P., Robinson, P. T., et al., Proc. ODP, Sci. Results, 118: College Station, TX (Ocean Drilling Program), 323-332.

Pezard, P., Howard, J. J., and Lovell, M. A., 1989. Clay conduction and pore structure of oceanic basalts from DSDP/ODP Hole 504B. In Becker, K., Sakai, H., et al., Proc. ODP, Sci. Results, 111: College Station, TX (Ocean Drilling Program), 97-108.

Pisciotto, K. A., 1981a. Diagenetic trends in the siliceous facies of the Monterey Shale in the Santa Maria region, California. Sedimentology, 28:547-571.

1981b. Distribution, thermal histories, isotopic compositions, and reflection characteristics of siliceous rocks recovered by the Deep Sea Drilling Project. In Warme, J. E., Douglas, R. G., and Winterer, E. L. (Eds.), The Deep Sea Drilling Project: A Decade of Progress. Spec. Publ.-Soc. Econ. Paleontol Mineral., 32:129-148.

Pittenger, A., Taylor, E., and Bryant, W. R., 1989. The influence of biogenic silica on the geotechnical stratigraphy of the Vøring Plateau, Norwegian Sea. In Eldholm, O., Thiede, J., Taylor, E., et al., Proc. ODP, Sci. Results, 104: College Station, TX (Ocean Drilling Program), 923-940.

Saunders, A. D., Storey, M., Gibson, I. L., Leat, P., Hergt, J., and Thompson, R. N., 1991. Chemical and isotopic constraints on the origin of the basalts from the Ninetyeast Ridge, Indian Ocean: results from Deep Sea Drilling Project Legs 22 and 26, and Ocean Drilling Program Leg 121. In Weissel, J., Pierce, J., Taylor, E., Alt, J., et al., Proc. ODP, Sci. Results, 121: College Station, TX (Ocean Drilling Program), 559-590.

Shipboard Scientific Party, 1989. Site 735. In Robinson, P. T., Von Herzen, R., et al., Proc. ODP, Init. Repts., 118: College Station, TX (Ocean Drilling Program), 89-222.

Smith, G. C., and Vine, F. J., 1987. Seismic velocities in basalts from CCSP Drill Holes CY-2 and CY-2a at Agrokipia Mines, Cyprus. In Robinson, P. T., Gibson, I. L., and Panayioutou, A. (Eds.), Cyprus Crustal Study Project: Initial Report, Holes CY-2 and CY-2a. Geol. Surv. Can., 295-306. 1989. The physical properties of diabases, gabbros and ultramafic rocks from CCSP Drill Hole CY-4 at Palekhori, Cyprus. In Gibson, I. L., Malpas, J., Robinson, P. T., and Xenophontos, C. (Eds.), Cyprus Crustal Study Project: Initial Report, Hole CY-4. Geol. Surv. Can., 295-314.

Tada, R., 1991. Compaction and cementation in siliceous rocks and their possible effect on bedding enhancement. In Einsele, G., Ricken, W., and Seilacher, A. (Eds.), Cycles and Events in Stratigraphy: Berlin (Springer-Verlag), 480-491.

Tada, R., and Iijima, A., 1983. Identification of mixtures of opaline silica phases and its implications for silica diagenesis. In lijima, A., Hein, J. R., and Siever, R. (Eds.), Siliceous Deposits in the Pacific region: Amsterdam (Elsevier), 229-245.

Tamaki, K., 1988. Geological structure of the Japan Sea and its tectonic implications. Chishitsu Chosasho Geppo, 39:269-365. 
Tamaki, K., Pisciotto, K., Allan, J., et al., 1990. Proc. ODP, Init. Repts., 127: College Station, TX (Ocean Drilling Program).

Taylor, E., 1991. Physical properties and consolidation of calcareous sediments of Broken and Ninetyeast ridges. In Weissel, J., Pierce, J., Taylor, E., Alt, J., et al., Proc. ODP, Sci. Results, 121: College Station, TX (Ocean Drilling Program), 253-260.

Urmos, J., Wilkens, R. H., Bassinot, F., Lyle, M., Marsters, J., Mayer, L., and Mosher, D., in press. Laboratory and well-log velocity and density measurements from the Ontong Java Plateau: new in-situ corrections to laboratory data for pelagic carbonates. In Berger, W., Kroenke, L., et al., Proc. ODP, Sci. Results, 130: College Station, TX (Ocean Drilling Program).

Wetzel, A., Williams, C., Kassens, H., Leger, G., and Auroux, C., 1990. Comparison between laboratory-determined physical properties and downhole measurements in outer Bengal Fan deposits. In Cochran, J. R., Stow, D.A.V., et al., Proc. ODP, Sci. Results, 116: College Station, TX (Ocean Drilling Program), 369-373.

Woodside, W., and Messmer, J. H., 1961. Thermal conductivity of porous media. J. Appl. Phys., 32:1688-1699.

Wyllie, M.R.J., Gregory, A. R., and Gardner, L. W., 1956. Elastic wave velocities in heterogeneous and porous media. Geophysics, 21:41-70.

Date of initial receipt: 17 July 1991

Date of acceptance: 26 February 1992

Ms 127/128B-219

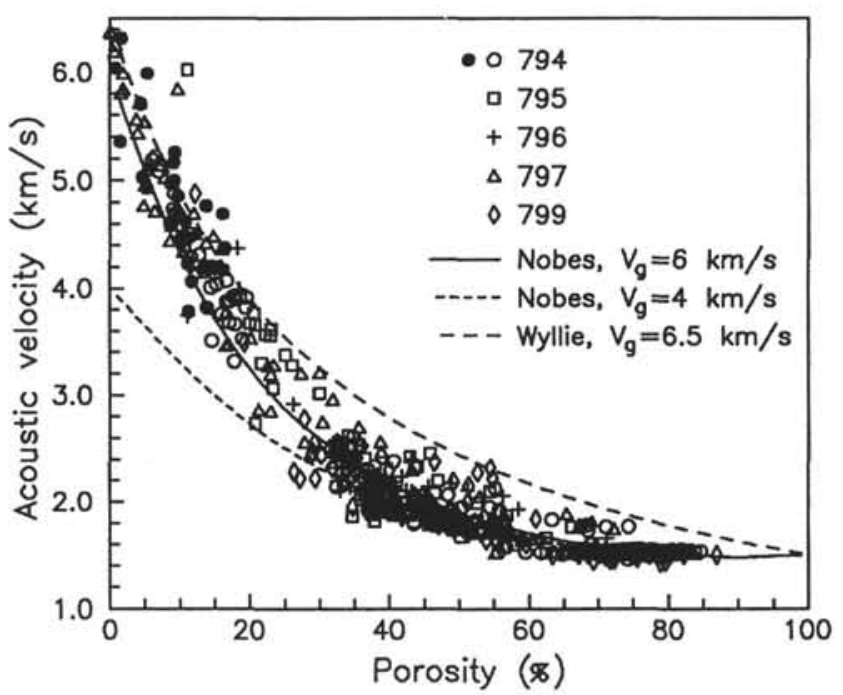

Figure 10. Acoustic velocity vs. porosity for all sites and lithologies. The sediment data for moderate to high porosities tend to follow the curves defined by the Nobes (1989) model. Grain velocities of $6 \mathrm{~km} / \mathrm{s}$ (solid curve), characteristic of silica, and $4 \mathrm{~km} / \mathrm{s}$ (short-dashed curve), characteristic of shale, tend to bracket the data and define a range of compositions from clay-rich (short dashed) to diatom-rich (solid). The igneous units tend to lie below the Wyllie et al. (1956) time-average curve (long-dashed curve) using a grain velocity that is approximately valid for unaltered basalt. 


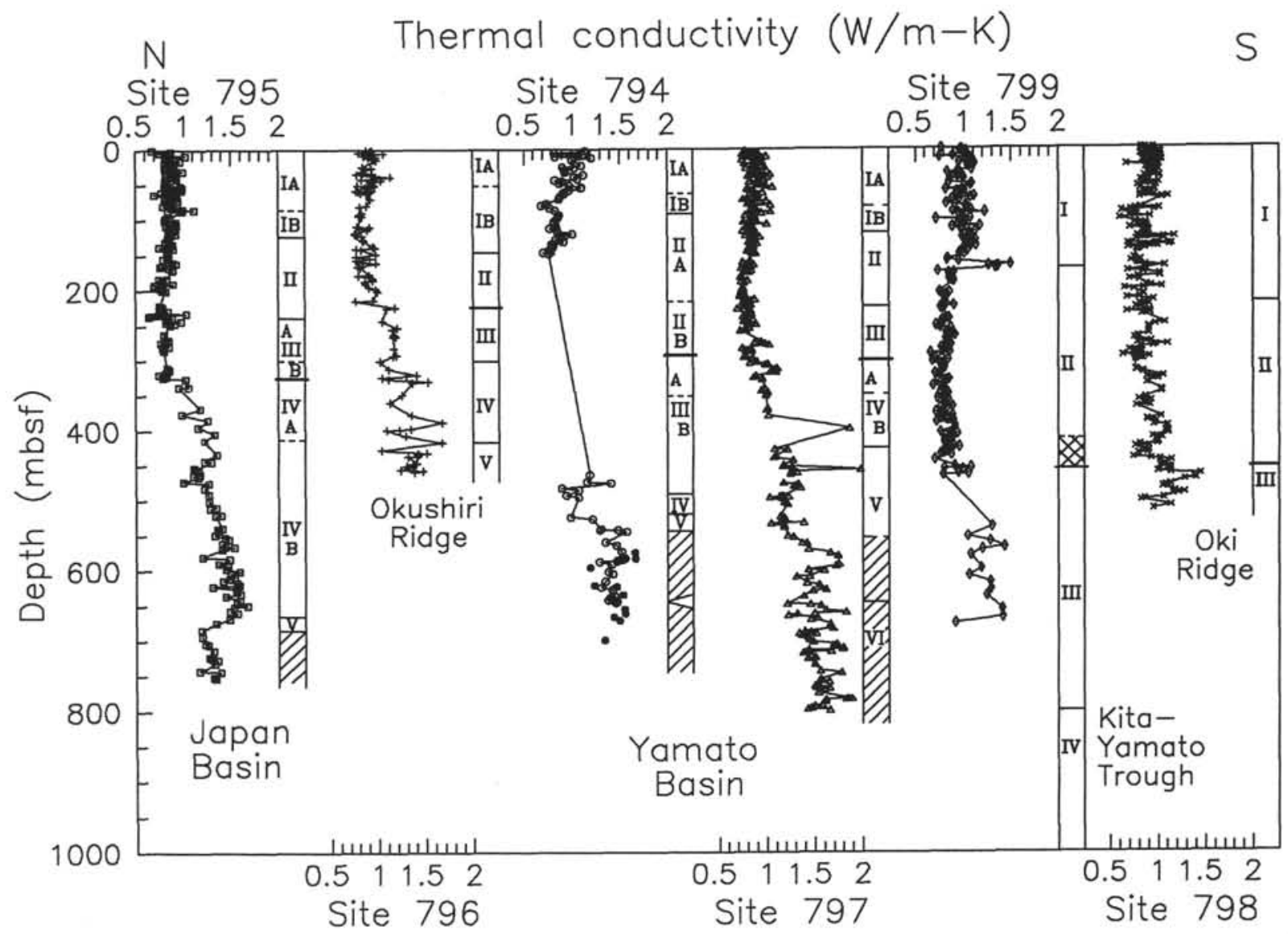

Figure 11. North-south profile of thermal conductivity from the northern Japan Sea (Site 795) to Oki Ridge (Site 798). Again, the opal-A to opal-CT transition shows as a sharp transition.

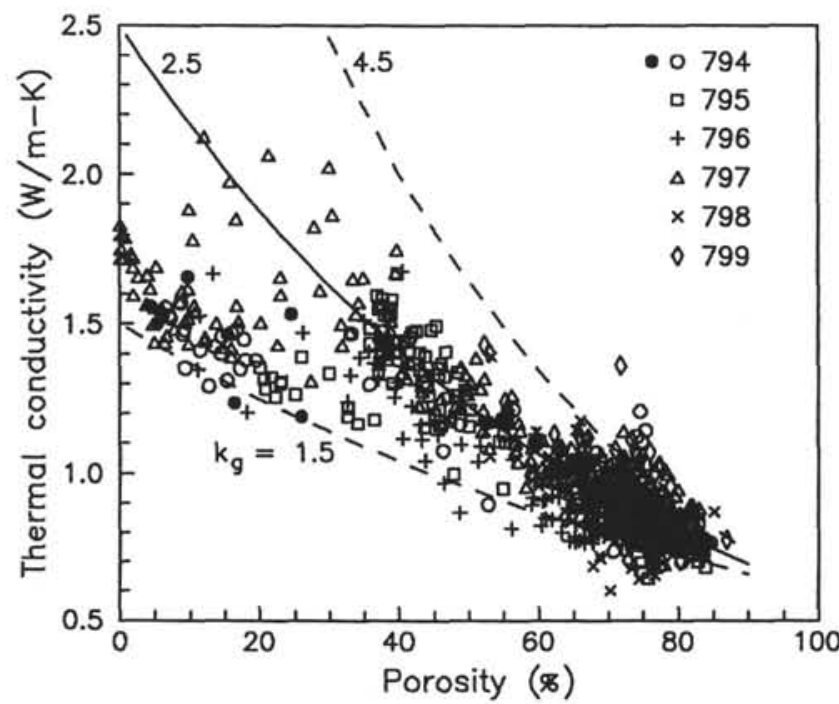

Figure 12. Thermal conductivity vs. porosity for all sites and lithologies. Theoretical geometric mean model curves are shown for grain thermal conductivities of 1.5 (lower dashed curve), 2.5 (solid curve), and 4.5 (upper dashed curve) $\mathrm{W} / \mathrm{m}-\mathrm{K}$. The sediment thermal conductivity data tend to cluster about the line for $k_{g}=2.5 \mathrm{~W} / \mathrm{m}-\mathrm{K}$, as expected; the igneous data (far left center) lie just above the $1.5 \mathrm{~W} / \mathrm{m}-\mathrm{K}$ line, in general agreement with previously obtained values of $1.7 \mathrm{~W} / \mathrm{m}-\mathrm{K}$ for basalts. 


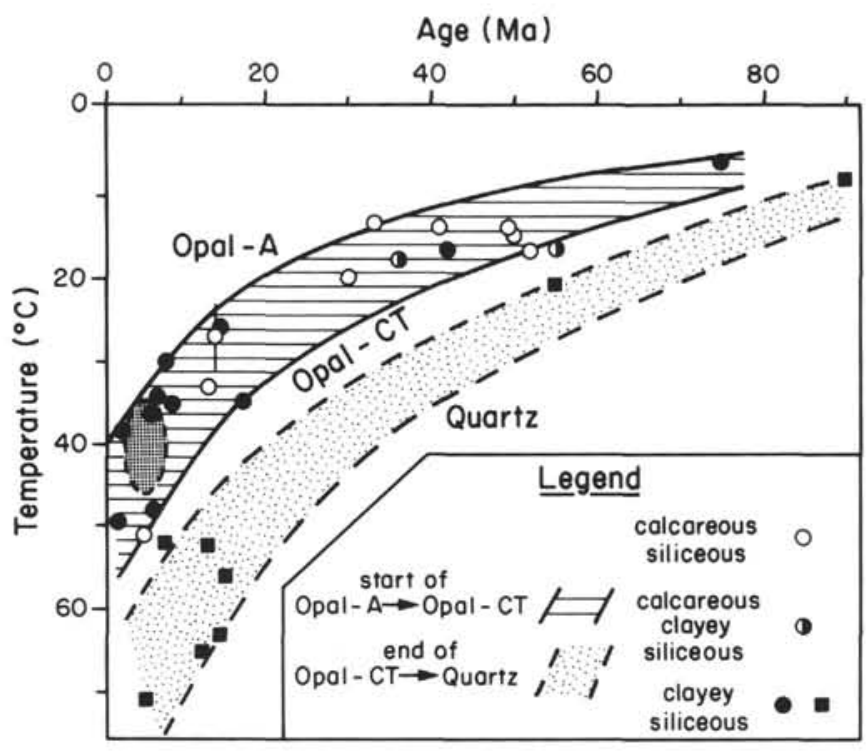

Figure 13. The occurrence of opal-A, opal-CT, quartz, and the diagenetic boundaries as a function of temperature and age. The opal-A to opal-CT transitions for Legs 127 and 128 are indicated by the shaded oval. (Adapted from Tada, 1991, via Kuramoto et al., this volume.)

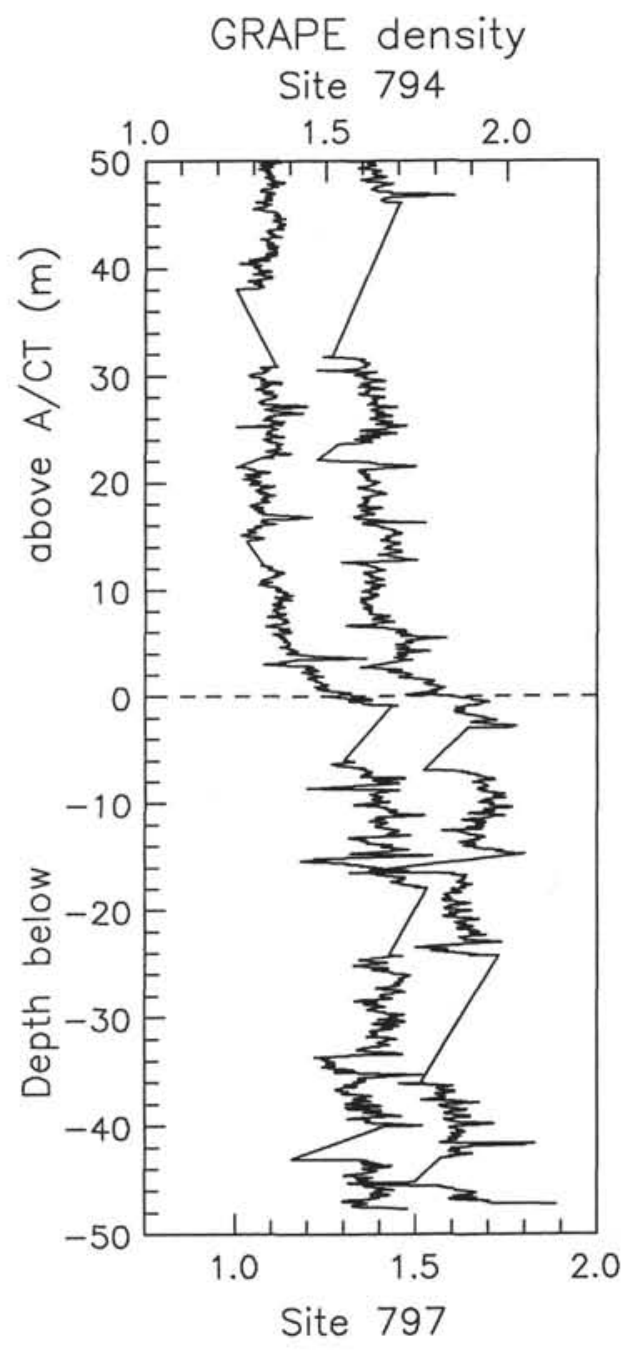

Figure 14. Detailed GRAPE density from Sites 794 (left) and 797 (right) across the opal-A/opal-CT boundary. The depths were adjusted so that the diagenetic boundary occurs at 0 ; thus data above the opal-A/opal-CT boundary have positive depths, and data below have negative depths. Note the trend of increasing density that starts at approximately $10 \mathrm{~m}$ above the boundary and accelerates in the last meter above the boundary. 


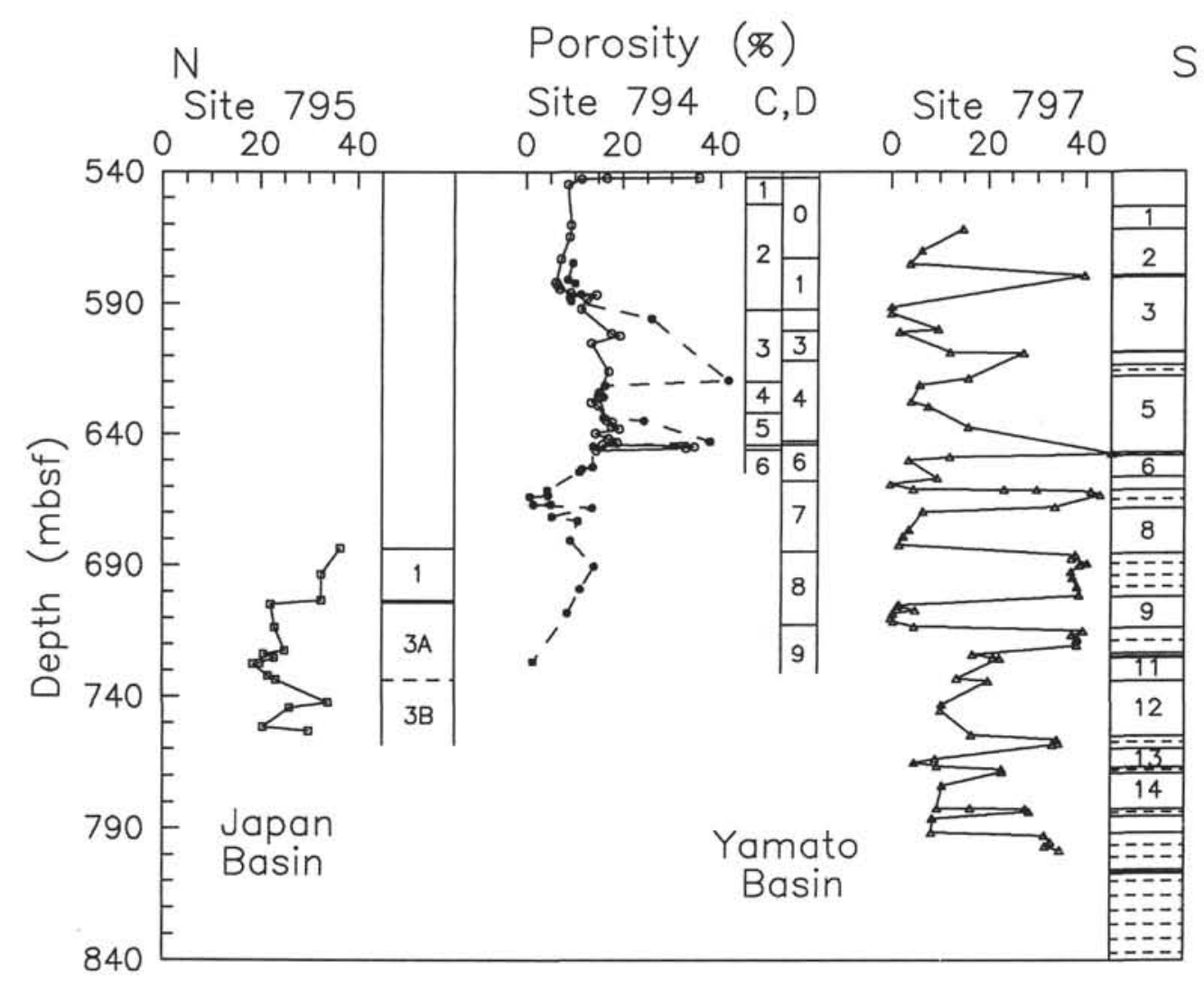

Figure 15. Porosity vs. depth in the igneous units of, from north to south, Sites 795, 794, and 797. The thinnest units have not been labeled. Sedimentary units are indicated by the horizontal dashed lines. Separate unit designations are shown for Legs 127 (Hole 794C, open symbols and solid curve) and 128 (Hole 794D, solid symbols and dashed curve). The unit boundaries were usually not recovered, and the boundaries are approximate. The boundaries between Units 2 and 3 and Units 5 and 6 for Hole 794C and between Units 1 and 2 and Units 4 and 6 for Hole 794D are well defined. Unit 5 in Hole 794D is a sedimentary layer that was recovered in both holes. Note the dramatic effects of the interbedding of sedimentary and igneous units in Site 797. (Based on Tamaki, Pisciotto, Allan, et al., 1990; Ingle, Suyehiro, von Breymann, et al., 1990.) 

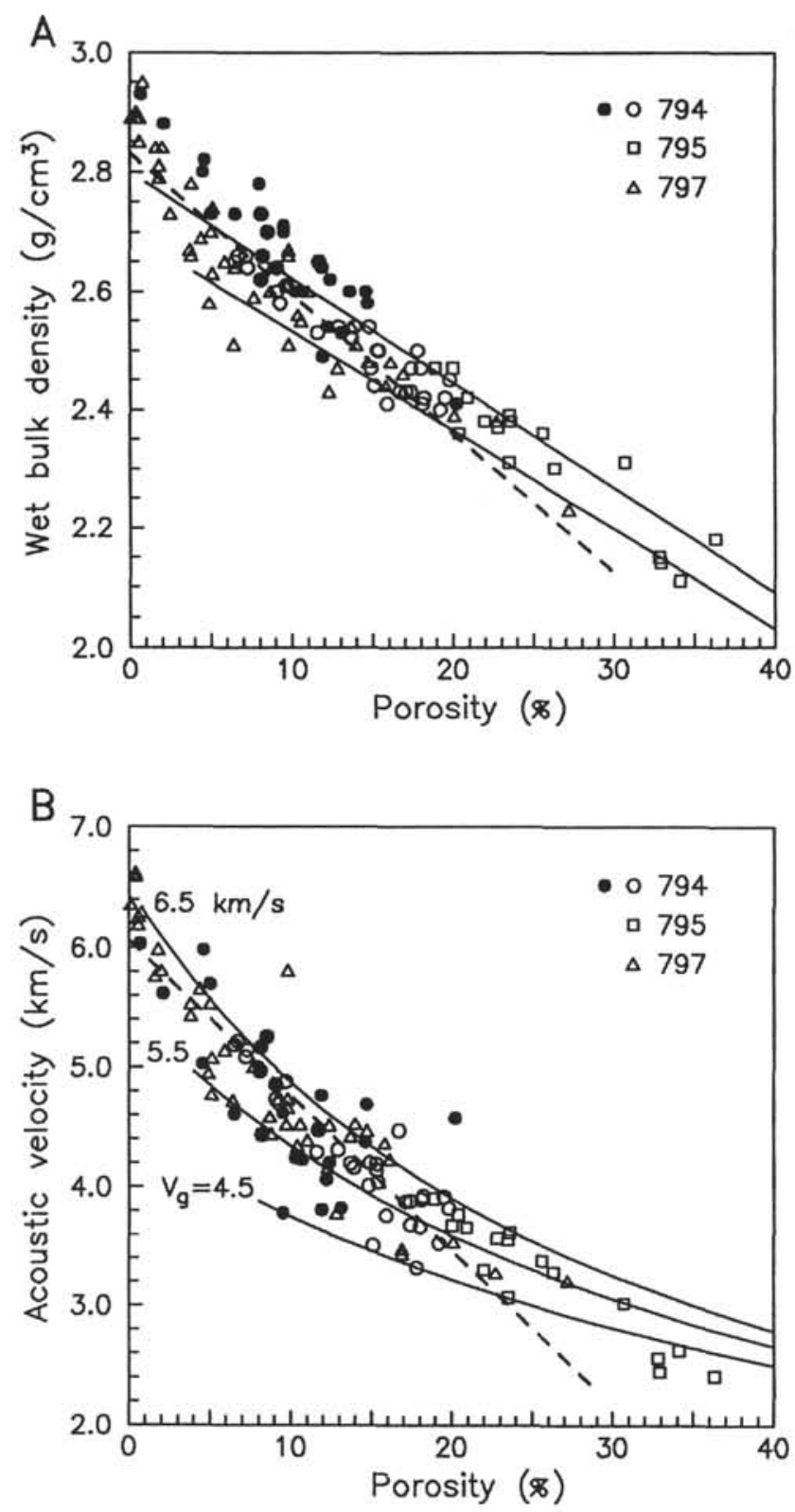

Figure 16. Wet-bulk density (A) and acoustic velocity (B) vs. porosity for the igneous units. Hole 794D data are shown as solid circles. The trend of the Site 797 data (dashed lines), which cover the greatest porosity range, crosses the theoretical mixing lines for grain densities of 2.7 (lower line) and $2.8 \mathrm{~g} / \mathrm{cm}^{3}$ (lower and upper solid lines, respectively, in Fig. 16A). The Site 797 trend also crosses two of the Wyllie et al. (1956) time-average velocity model curves (solid lines in Fig. 16B) for grain velocities of $6.5,5.5$, and $4.5 \mathrm{~km} / \mathrm{s}$, illustrating the effects of igneous alteration as a function of porosity.

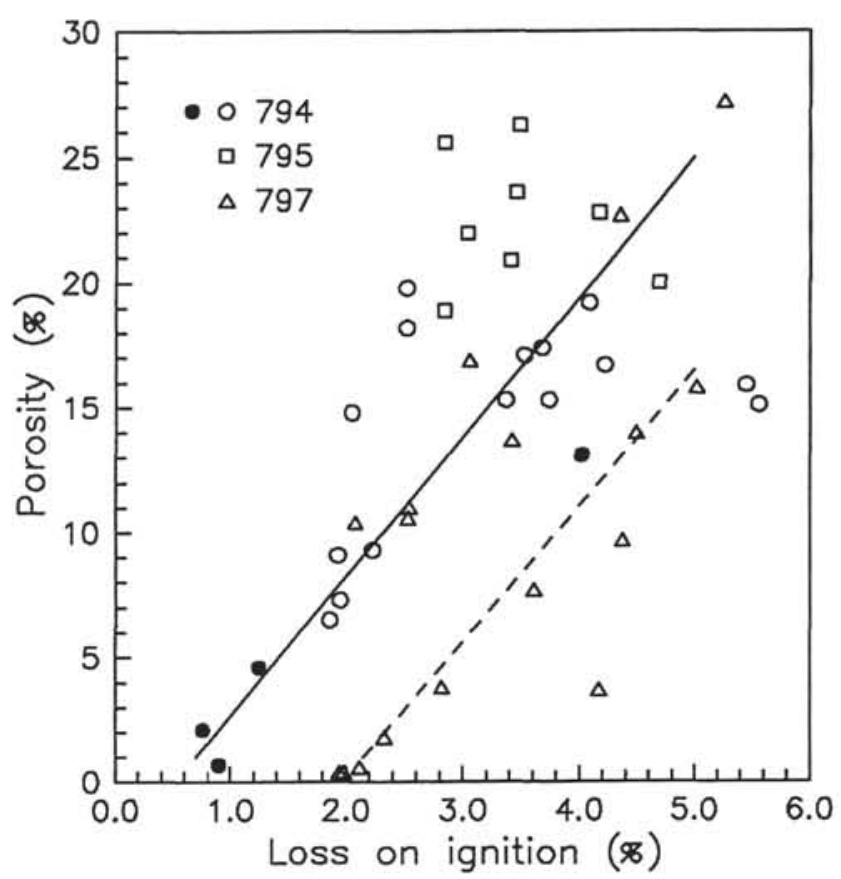

Figure 17. Loss on ignition best characterizes the degree of alteration, and the porosity is in turn correlated with the LOI. 

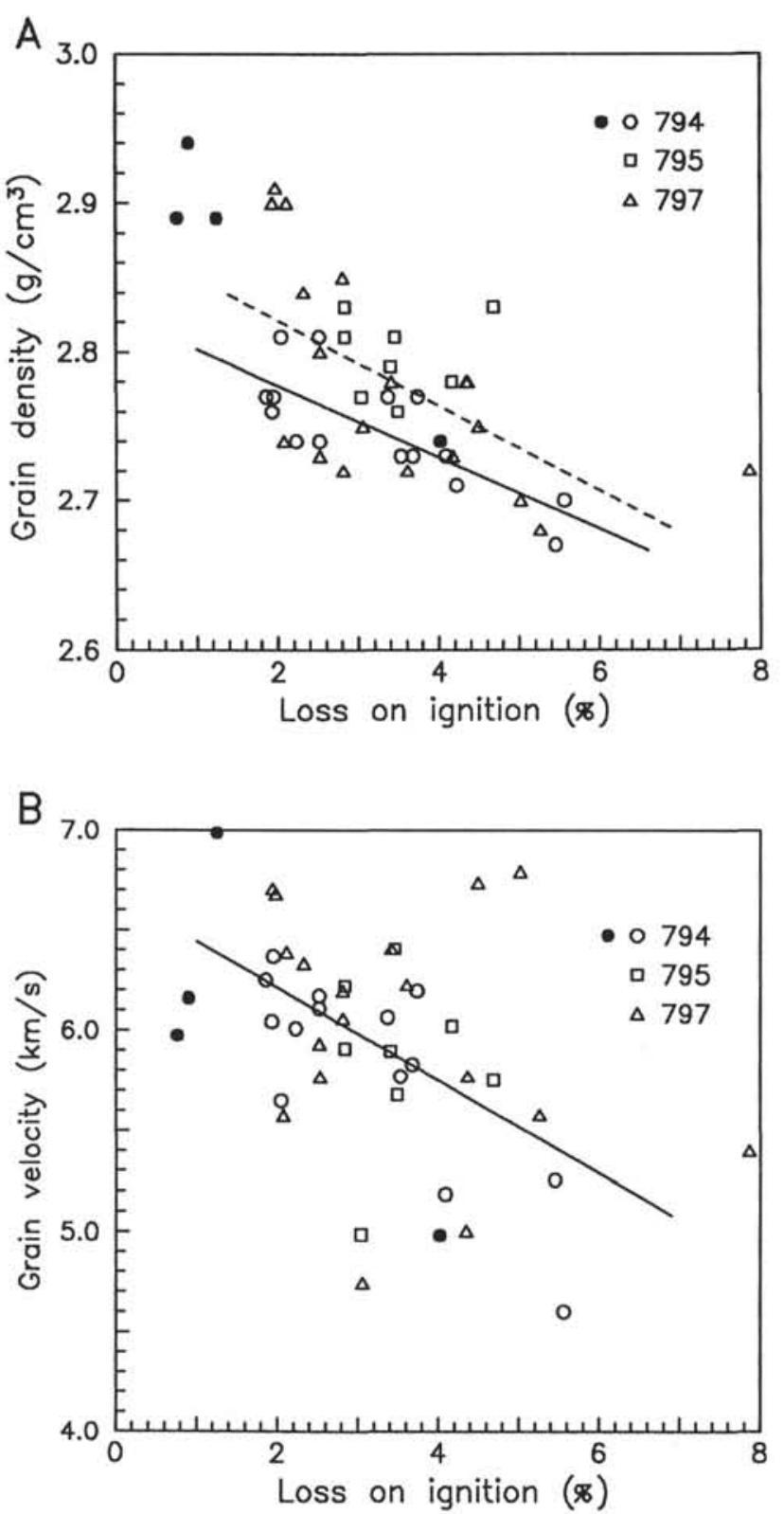

Figure 18. Grain properties vs. loss on ignition broadly illustrate the effects of alteration. The Hole 794C data (open circles) cover the broadest LOI range, and best illustrate the effects of alteration on the physical properties. The grain density (A) and grain velocity (B) decrease as the degree of alteration increases (solid lines). The grain density for Site 797, although more scattered, also shows a similar trend (dashed line). 
D. C. NOBES ET AL.

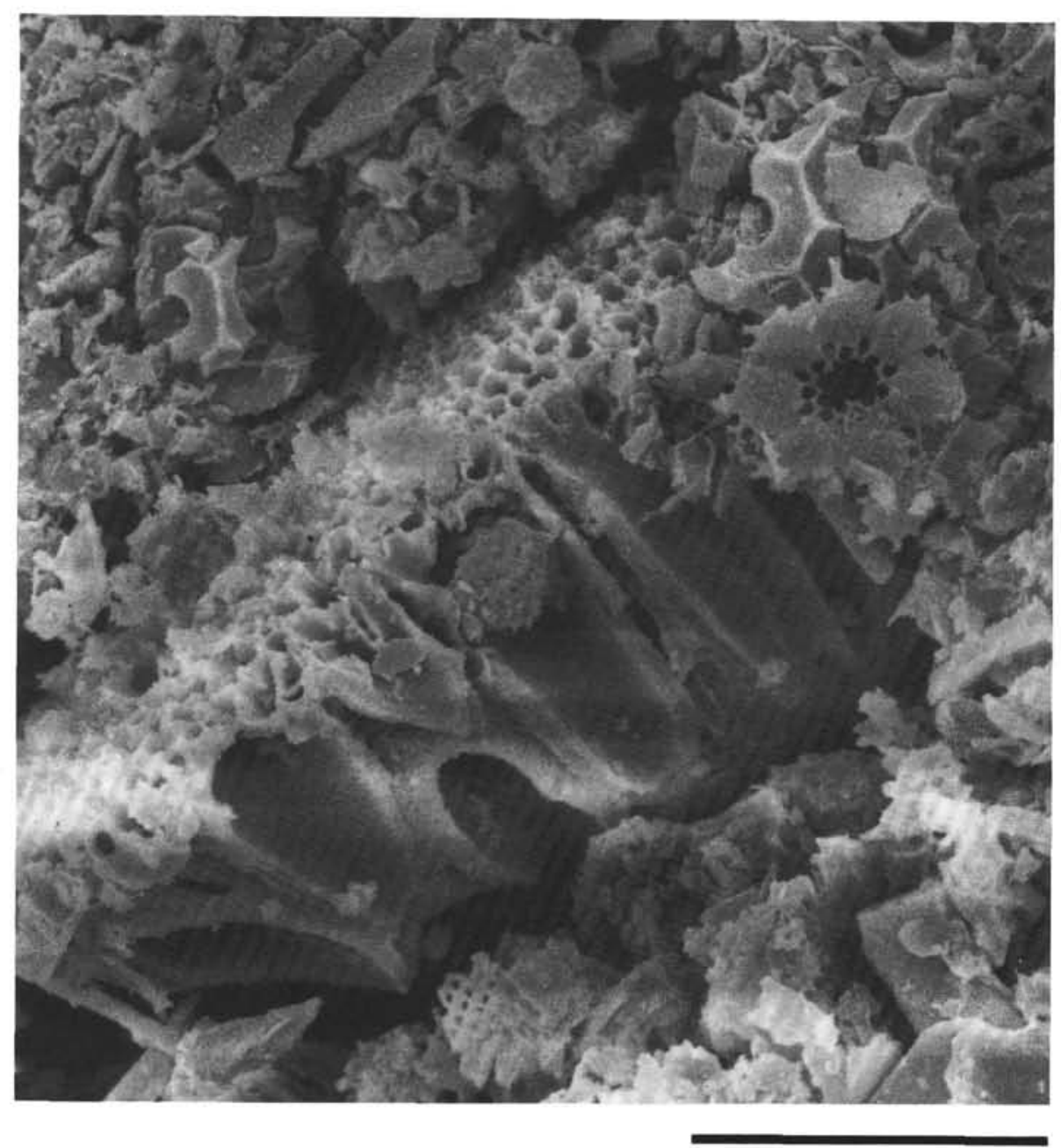

Plate 1. Photograph of a scanning electron microscope (SEM) image from Sample 127-795A-34X-3, 100-102 cm, (311.90 mbsf) showing the open cellular structure apparent in a diatom fragment. The scale bar is $10 \mu \mathrm{m}$. 


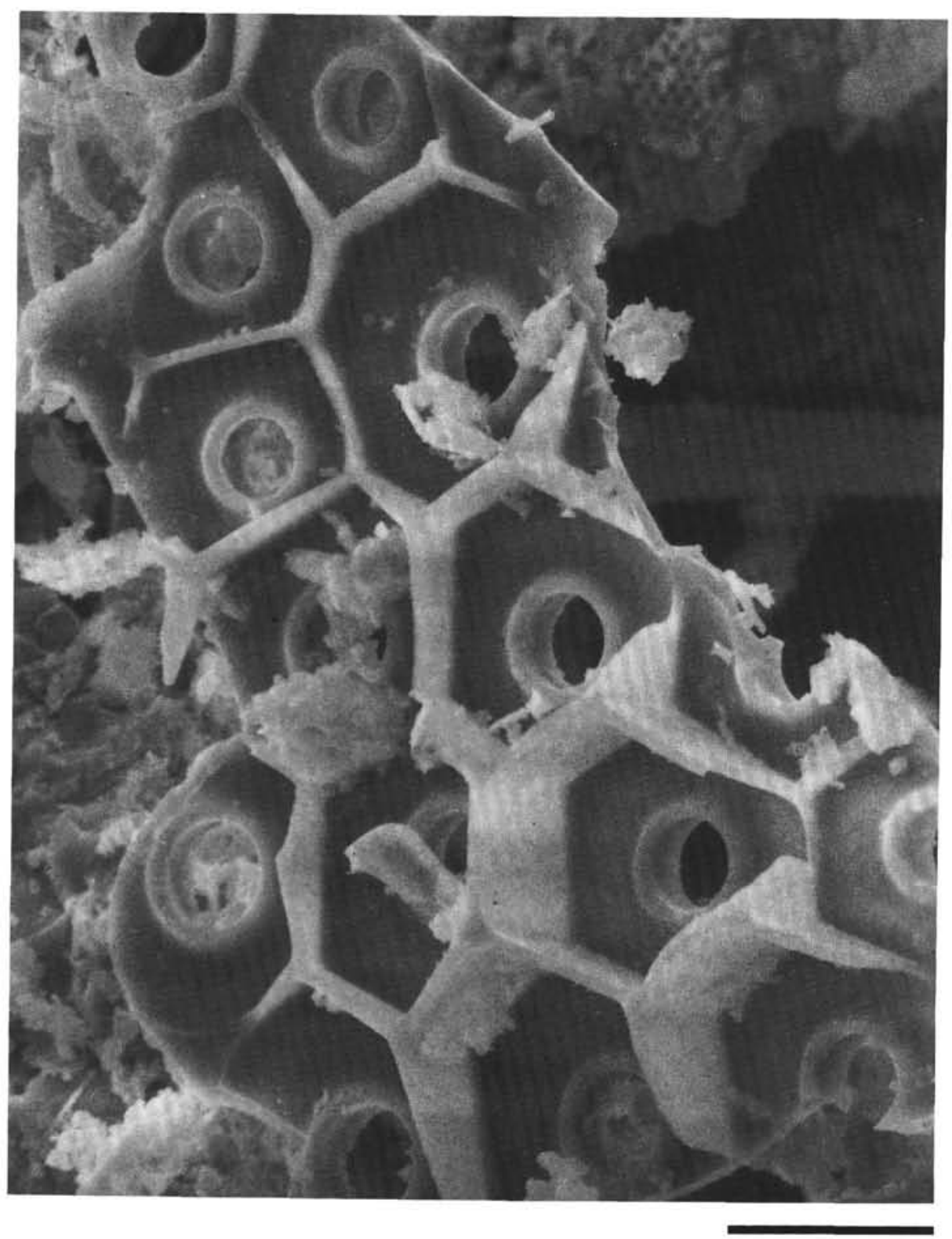

Plate 2. SEM image from Sample 127-795A-35X-3, 100-102 cm, (321.60 mbsf) showing the open internal structure of a relatively pristine fragment. The scale bar is $2 \mu \mathrm{m}$. 
D. C. NOBES ET AL.

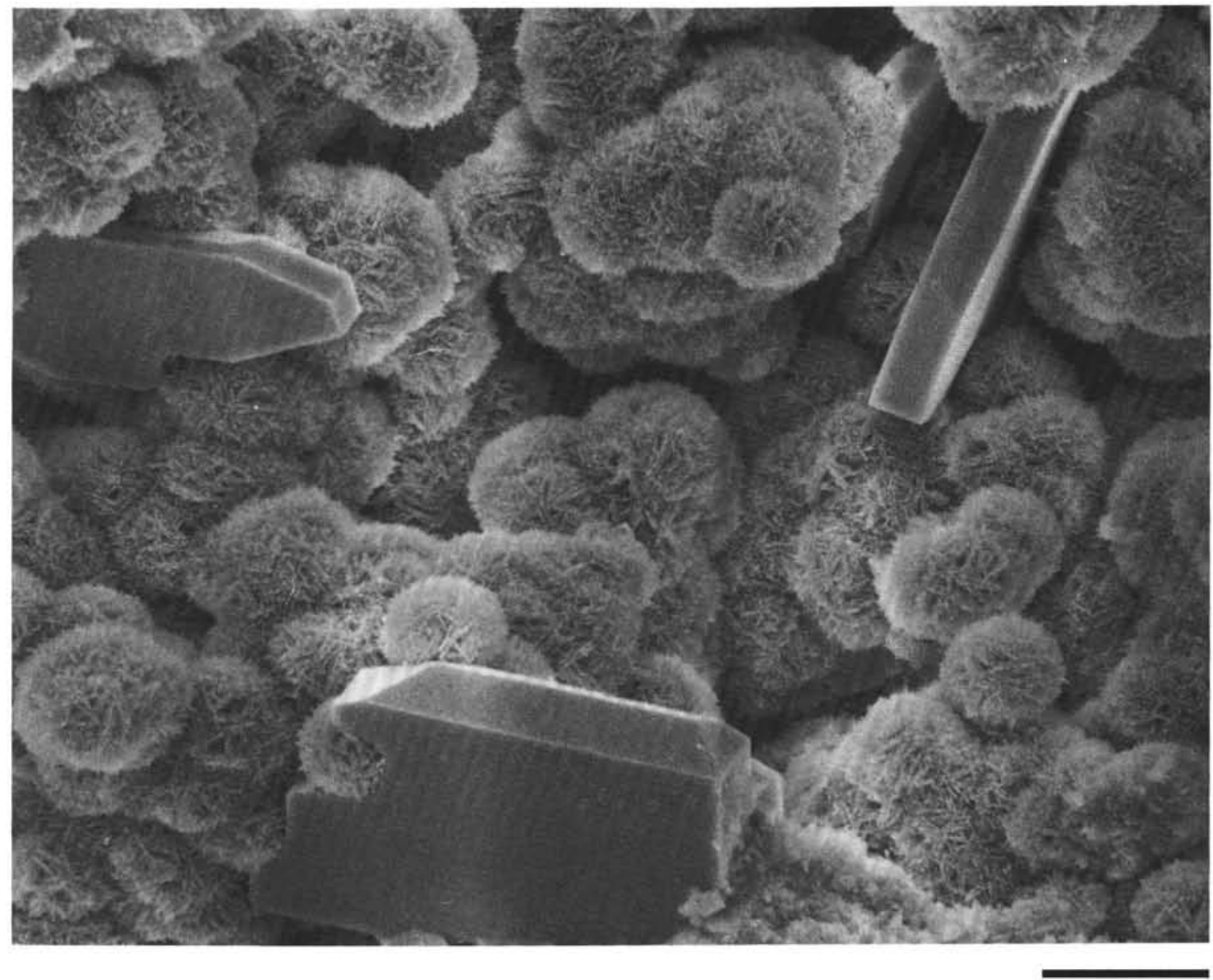

Plate 3. SEM image from Sample 127-797B-46X-1, 40-42 cm, (427 mbsf) showing characteristic "coffin-shaped" clinoptilolite (zeolite) crystals (Mumpton and Ormsby, 1978) surrounded by abundant opal-CT. The scale bar is $10 \mu \mathrm{m}$. 


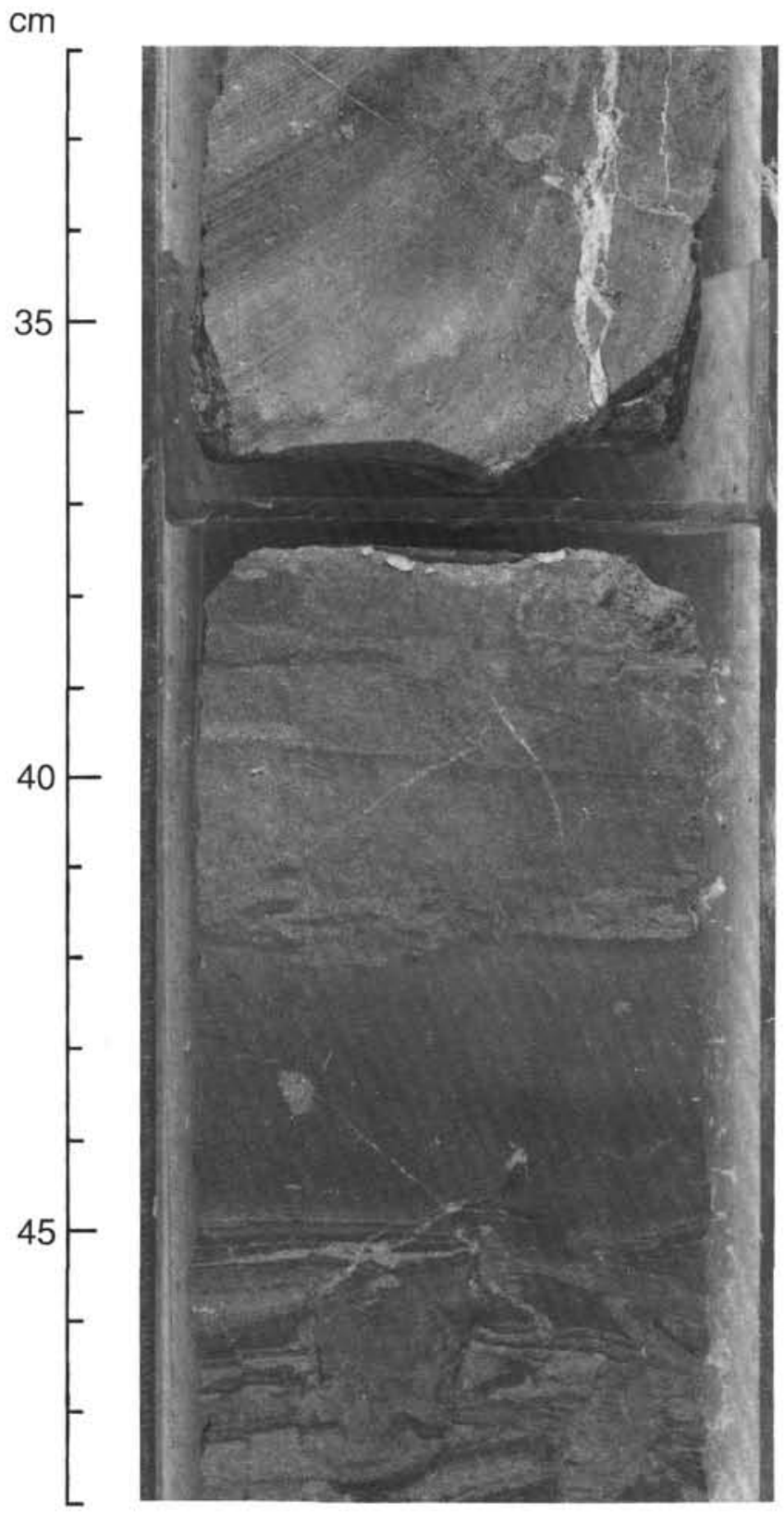

Plate 4. Close-up photograph of Section 127-797C-22R-1, 32-48 cm, showing the contact between the upper aphyric dolerite and the underlying siltstone and claystone, an example of the interbedding of igneous and sedimentary units common at Site 797. 


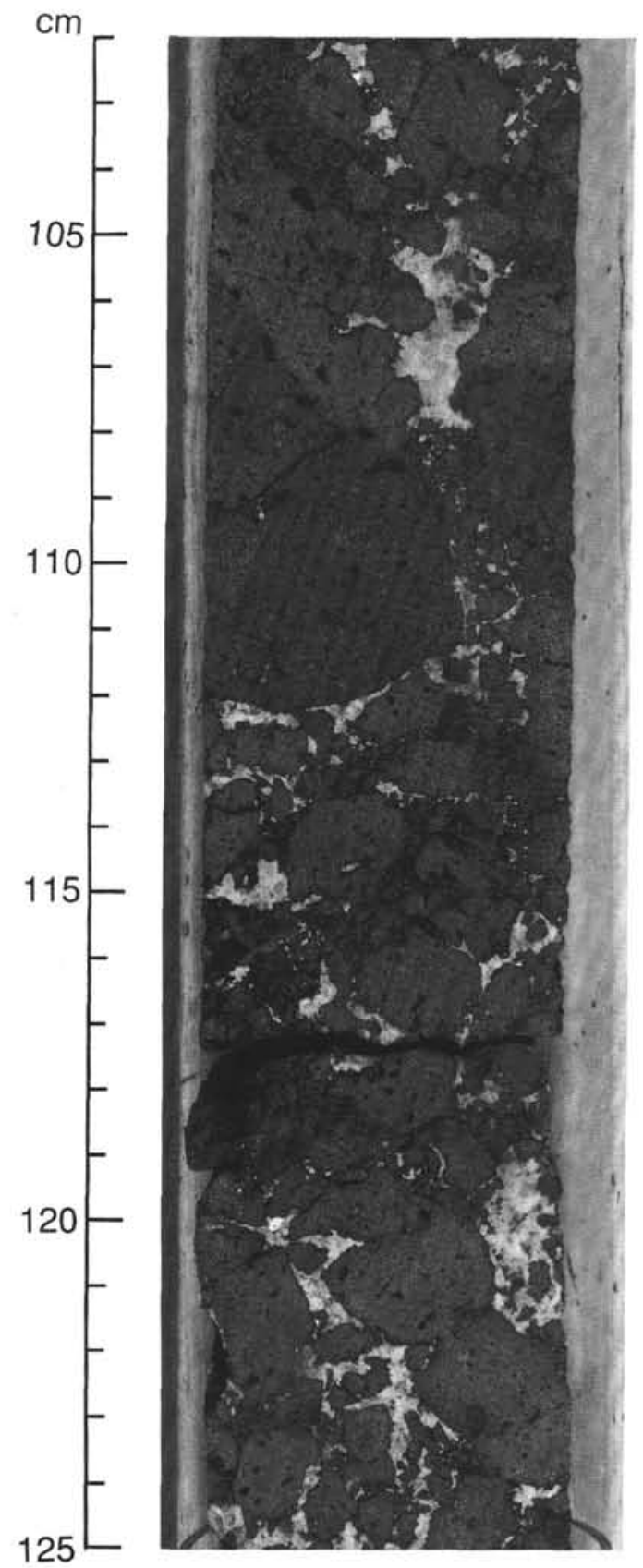

Plate 5. Close-up photograph of Section 127-795B-40R-1, 102-125 cm, showing the brecciation that is typical of igneous Unit 3 at Site 795 . 